\title{
Breve historia de la taxonomía del cuerpo y del pecado en el arte costarricense
}

Sussy Vargas Alvarado

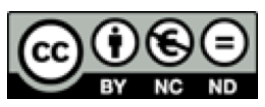

Esta obra está bajo una licencia Creative Commons

Reconocimiento-No comercial-Sin Obra Derivada 

Artículos

\title{
Breve historia de la taxonomía del cuerpo y del pecado en el arte costarricense
}

\author{
Sussy Vargas Alvarado \\ Escuela de Artes Plásticas. Universidad de Costa Rica \\ sussyvargasart@gmail.com
}

Recibido: 16 de enero del 2016 Aprobado:18 de febrero de 2016

Resumen

A partir de una taxonomía del arte, se propone una investigación sobre el tema del cuerpo, el desnudo, el deseo y cómo estos han sido sistemáticamente censurados en los espacios expositivos costarricenses por su relación con el pudor, lo inadecuado y el pecado. A pesar de la censura, algunos artistas costarricenses han trabajado el tema del cuerpo desde diferentes perspectivas y visiones, con discursos alternativos que intentan abordar lo erótico y el deseo como una parte normal de la vida del ser humano. La presente investigación formula un inventario resumido desde las culturas precolombinas hasta las últimas expresiones artísticas contemporáneas, con el afán de estudiar los diferentes contextos en donde la censura y la prohibición han tomado lugar en el arte costarricense.

Palabras clave: taxonomía, cuerpo, prohibición, deseo, erótica, pecado, desnudez, normalización social, homoerotismo, censura, heteronormativo.

\begin{abstract}
From the taxonomy of art, this investigation proposes a look into the theme of the body, nakedness and desire, which have been systematically censored from the exhibition spaces in Costa Rica, due to the relation they have with what is improper, inadequate and sinful. In spite of the censure, few Costa Rican artists have worked the theme of the body from different perspectives, with alternative points of view to use the body image to talk about eroticism and desire as a normal part of the life of any human being. This investigation tries to create a summarized inventory which goes from the pre-Columbian culture expressions to the latest more contemporary ones, with the main objective of studying different context where the censure has taken place in the Costa Rican art.
\end{abstract}

Key words: taxonomy, body, prohibition, desire, erotic, sin, nudity, social normalization, homoerotismo, banned, heteronormativy. 


\section{Artículos}

El término taxonomía pertenece más al ámbito de la ciencia que al del arte; sin embargo, en su sentido más general, la taxonomía (del griego $\tau \alpha \xi_{\iota \varsigma,}$, taxis, 'ordenamiento' $\mathrm{y}$ vo $\mu$ oc, nomos, 'norma' o 'regla') es la ciencia de la descripción y de la clasificación de los elementos; por tanto, es posible realizar una taxonomía también del arte. Los humanos han sido clasificados de muchas maneras por la ciencia, desde la biología a la morfología, como animales cordados, mamíferos, primates, homínidos, Homos y Homo sapiens. El cuerpo ha sido esculcado desde lo visible hasta lo invisible con la invención de los Rayos $\mathrm{X}$ en 1887; con la proliferación de imágenes médicas, antropológicas y etnográficas se ha hurgado el cuerpo hasta la saciedad, y con la tecnología -cada vez más- se ha llegado hasta la desmaterialización molecular del mismo.

Además, el cuerpo como constructo social, “[...] está siendo repensado y reconsiderado por artistas y escritores porque está siendo reconstituido por científicos e ingenieros" (Ewing, 1994, pág.9). Por otro lado, el cuerpo ha sido idealizado y desacralizado a través del arte $y$, en este proceso, la fotografía ha jugado un papel primordial en la transformación del cuerpo en carne real, evidencia, vello, fluido y pubis.

La pregunta es: ¿se puede realizar una taxonomía del arte relacionado con el cuerpo y sus prohibiciones en el arte costarricense? Por tanto, en el presente ensayo se busca inventariar los antecedentes en los que el tema del cuerpo y la desnudez han tenido ciertas regulaciones, impedimentos o censura, a partir del análisis de ejemplos muy particulares dentro del escenario en el cual se han desarrollado. En dicho contexto, se destaca el papel de la moral y las normas sociales presentes alrededor del tema- las cuales han estado muy ligadas con lo religioso; en este sentido, pareciera que "cuerpo", "prohibición" y "pecado", son conceptos que van de la mano.

En primera instancia, resulta pertinente definir el concepto de "pecado". El pecado ha sido relacionado con todas las prácticas humanas que se salen del orden establecido y de las normativas sociales instauradas como medio para controlar o regular a los individuos. Dependiendo de las creencias, el término "pecado" se define como un delito moral, realizado de manera voluntaria. Tan sólo el catolicismo se ha ocupado en crear una especialización sobre el tema, clasificándolos en: a) "pecado original", el cual fue cometido por Adán y Eva, y trae a colación la desobediencia en la búsqueda del conocimiento y la vergüenza ante la propia desnudez; b) los "diez mandamientos", planteamientos que establecen las reglas de comportamiento social y cuya transgresión acarrea un castigo; c) "pecados capitales", los cuales incluyen lujuria, gula, avaricia, pereza, ira, envidia y soberbia; d) "pecados veniales", considerados menores y perdonados mediante los sacramentos de la Iglesia; e) "pecados mortales", los cuales implican la condenación eterna; entre ellos es posible encontrar la blasfemia, la brujería, el incesto, la fornicación, el suicidio y el sacrilegio. Finalmente, se encuentran los f) "pecados nefandos" (también llamados bestiales), considerados los más 
perversos y abominables por la Iglesia, pues implican aquellas prácticas sexuales que se ejercen dentro del espacio privado con el único propósito de satisfacer los deseos del individuo (masturbación, zoofilia, homosexualidad, entre otros).

Se hace evidente entonces que muchas de estas normativas están relacionadas de forma directa o indirecta con el cuerpo, el cual se convierte en el centro de las debilidades humanas y establece así una conexión con el pecado original y, a su vez, con la vergüenza acarreada por la desnudez. En consecuencia, a lo largo de los siglos se ha generado una suerte de nudofobia ${ }^{1}$, la cual se ha prolongado a través del tiempo, por lo que es realmente difícil pretender que esta no alcance la contemporaneidad del siglo XXI.

La fotografía, en este inventario de capas existenciales, ha cumplido su papel a cabalidad, haciendo que se mire el cuerpo humano con la más absoluta fragilidad y perturbadora corporeidad. Por medio de la fotografía, el cuerpo se volvió fragmentario. Ha sido posible documentar el proceso de la gestación de un ser humano, hasta la completa degradación de la muerte. Se han fotografiado cuerpos heridos, transformados, dislocados, rediseñados; se ha hurgado en entrañas y documentado la energía invisible que circunda (aura). Se ha idealizado el cuerpo a partir de los imaginarios publicitarios, que hacen dudar de la propia realidad corporal; así, el cuerpo se ha convertido en el espacio donde se depositan los discursos alrededor de lo político, lo normativo y lo regulado socialmente.

A pesar de estas regulaciones, el cuerpo se ha ocultado, erotizado, sexualizado y hasta sodomizado, tanto por la sociedad como por el arte mismo. Este se ha visto transformado en un objeto de deseo y de los intereses de la publicidad, del comercio y de la enajenación. En este sentido, las nuevas tecnologías han roto la frontera de lo permisible, dando lugar a que estas imágenes transgresoras se filtren cada vez más en la cotidianidad; desde la llegada del cine y, más adelante, con la posibilidad de las videocaseteras y los VHS, se pudo integrar lo prohibido a lo íntimo. El impacto de Internet y de los dispositivos inteligentes ha creado un puente de acercamiento a imágenes cada vez más explícitas que contravienen la absoluta normalidad, es decir, de lo que no se quiere hablar. Conceptos nuevos surgen para nombrar las posibilidades de acercamiento al tema del cuerpo y a nuevas realidades virtuales, por medio de dispositivos en 3D, 4D, 7D y hologramas, conduciendo, de esta forma, a imaginarios del deseo casi imposibles de visualizar apenas diez años atrás.

\footnotetext{
${ }^{1}$ Nudofobia: Se define como un persistente, anormal e injustificado miedo a la desnudez. "El término proviene del latín "nudus" (desnudo) y del griego "phobos" (miedo). Según el psicoanálisis, esta fobia es un síntoma del conflicto entre el deseo del individuo de mostrarse tal cual realmente es, y el miedo a las consecuencias en el caso de hacerlo" (Nudofobia, s.f.)
} 


\section{Artículos}

Figura 1

Representaciones fálicas y eróticas. Colección Museo de Jade

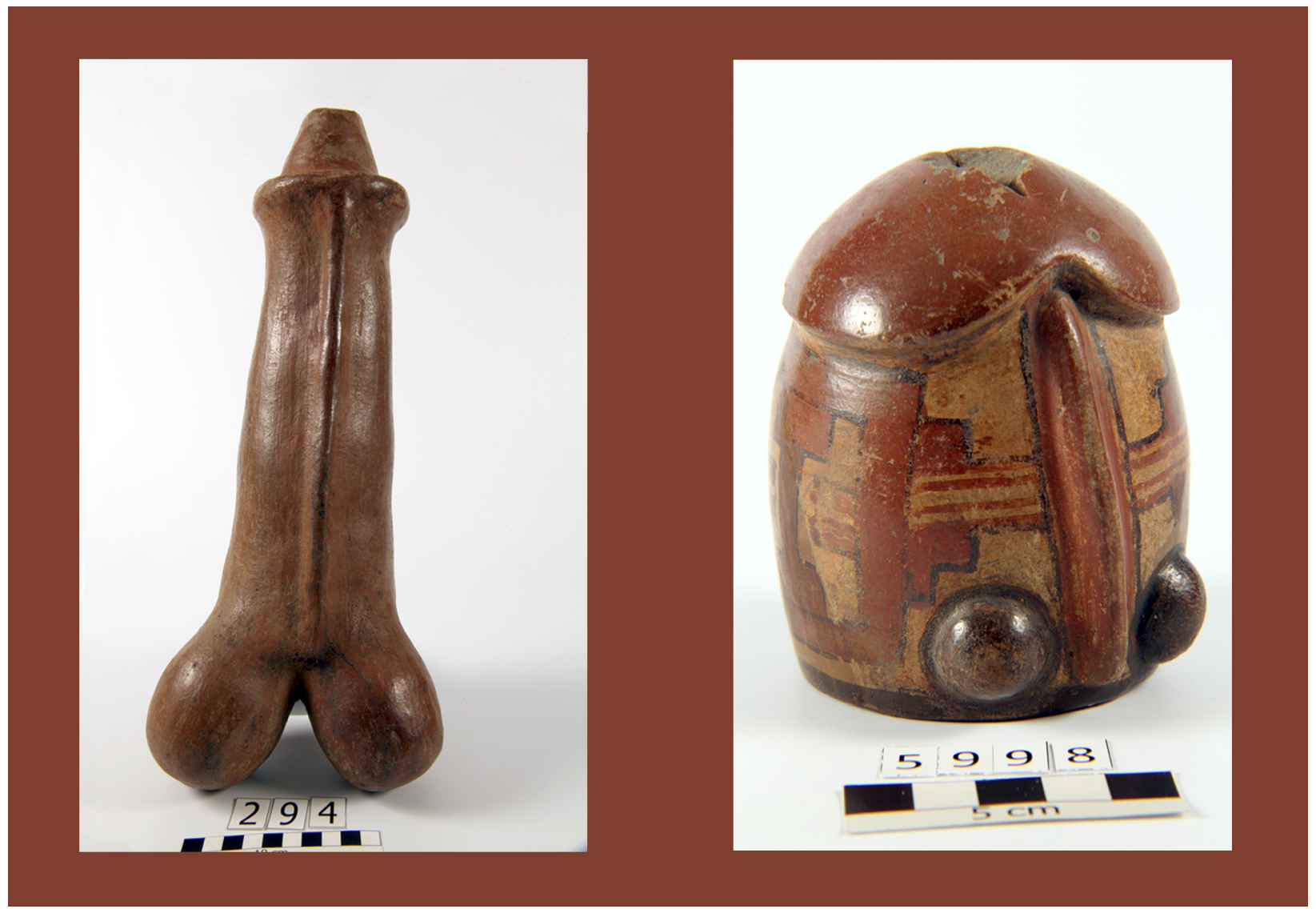

Fuente: Museo de Jade

No obstante, el tema del cuerpo se acerca a los márgenes de lo permitido socialmente. Aspectos como el deseo, la diversidad sexual, la ruptura de los roles impuestos por el patriarcado, los cuestionamientos hacia la masculinidad, el derecho a plantear y asumir la propia sexualidad y, por ende, la reafirmación constante de una identidad; la desobediencia como herramienta política contra doctrinas religiosas, $y$ la irreverencia hacia lo permitido, hacen que la referencia al cuerpo implique hablar de cómo la sociedad ha establecido normas bajo las cuales se le puede o no mostrar.

Para hablar entonces de etapas muy definidas en esta división de las permisiones corporales en el arte costarricense, sería necesario remitirse un poco más atrás en la historia, para entender el contexto de estas 
prohibiciones. Esto plantea contradicciones entre la capacidad que tenían las culturas indígenas para expresarse alrededor de la sexualidad y del cuerpo, y el tabú que sobre el mismo fue heredado por la visión occidental. Temas como el placer, la copulación, la homosexualidad o la genitalización, eran elementos fundamentales de las culturas autóctonas en su cotidianidad y, en su mayoría, eran usados como parte de ritos de fecundidad.

Existe un miedo al cuerpo y a la desnudez. De forma aparente, evitar abarcar el tema es la forma en que se desvanece el engorro que genera el pensar cómo los antepasados exaltaron el cuerpo, los genitales o el sexo.

Sigue siendo fascinante cómo estas piezas que hoy se conservan en el Museo de Jade, expuestas nuevamente y a la vista de todos, aún generan esa curiosidad y particular incomodidad (Fig. 1). Estas fueron mostradas en la antigua sede del Museo del Jade, cuando formaba parte del edificio del Instituto Nacional de Seguros (INS) y fungía como directora del Museo la Lic. Zulay Soto Méndez. Según narra Soto Méndez ${ }^{2}$, las piezas fueron mostradas como parte de la exposición La Fecundidad, la cual se exhibió en la Sala de Exposiciones Permanentes Fidel Tristán (4 de agosto de 1984), durante la inauguración de la Cuarta Reunión del Comité Latinoamericano del ICOM. La misma generó muchísima controversia, tanto en los participantes como en los funcionarios del INS y, a pesar de que solicitó eliminar de la muestra, los falos sobrevivieron a la censura antes de ser llevados al depósito, donde permanecieron guardados por mucho tiempo.

El falo, como representación de la fecundidad en las culturas indígenas, tenía misteriosas propiedades mágicas, místicas y religiosas. El órgano masculino era el elemento que fusionaba el poder vital de la vida con la naturaleza y, de forma especial, con la tierra, por lo cual era parte de los rituales de siembra, además de haber estado relacionado con el culto al sol, como fuente vital de energía y de vida. También solía estar presente en ritos de iniciación para las jóvenes doncellas:

Las costumbres sexuales y morales de los indígenas formaban parte del carácter humano universal. Las antiguas culturas de América consideraban al igual que los antiguos griegos el coito como una revelación divina, un rito de fertilidad sin aspectos morales o sexuales. Desconocían el concepto cristiano según el que una descripción o representación de la unión sexual sería vil. (Krumbrach , 1996, p.6)

\footnotetext{
${ }^{2}$ Información recuperada de las conversaciones realizadas con Lic. Zulay Soto-Méndez, en febrero de 2016. En ellas, la curadora relata cómo se le solicitó que las piezas - de forma específica, los falos precolombinos-fueran eliminadas de la muestra, a lo que ella, como directora, se negó. En consecuencia, las piezas fueron parte de la exposición, durante varias semanas.
} 


\section{Artículos}

Resulta interesante observar la resemantización que realiza la ceramista Tamara Ávalos en su proyecto: Hija de Eva (MAC. 2008), el cual se apropia de las técnicas y lenguajes indígenas para crear cerámicas en donde el cuerpo femenino asume su total libertad para el deseo y el placer. Ávalos se apropia de estas técnicas tradicionales y las mezcla con materiales y lenguajes contemporáneos para reivindicar este sentido, casi misterio, de la sexualidad sagrada y el papel de la mujer en "[...] una revisión y reconstrucción del arquetipo femenino encarnado por Eva" (Monge, 2008, p.5).

Por otro lado, muy pocas manifestaciones alrededor del tema del cuerpo en la Época Colonial, en Costa Rica, han sido encontradas. Es posible citar como excepción el detalle del camarín, propiedad del Museo $\mathrm{Nacional}^{3}$, donde unos mal esbozados Adán y Eva, en una posición bastante sugerente, son parte del imaginario del pecado original (Fig. 2).

Aparte de esto, las imágenes religiosas que llegan al país y las que se empiezan a confeccionar en Costa Rica, en la misma época, no pasan de ser imágenes sencillas, como por ejemplo los ángeles (Querubines) que son parte de la decoración de la Iglesia de Orosí. Todas las otras representaciones religiosas mostraban una completa negación del cuerpo desnudo.

Dentro de la misma colección del Museo Nacional de Costa Rica se exhibió, por mucho
Figura 4

Detalle Camarín (s.f.)

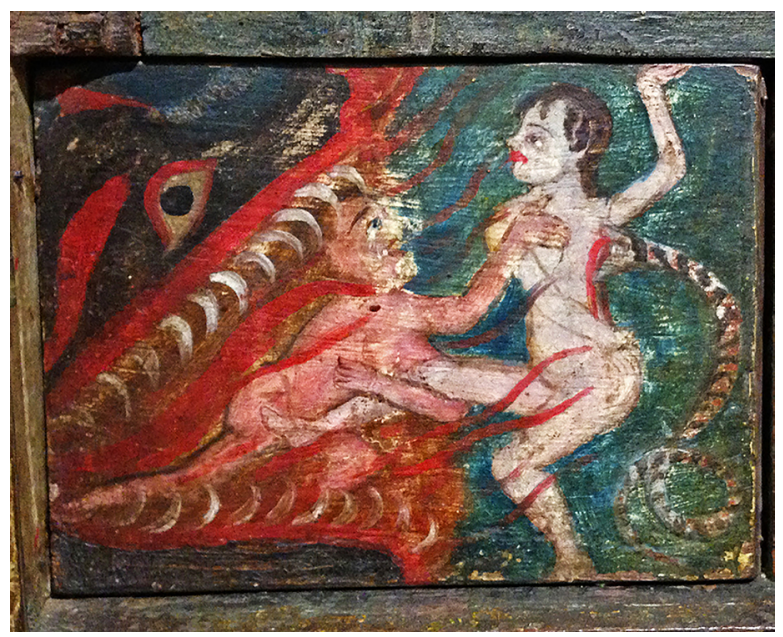

Fuente: Colección MNCR

tiempo, en la antigua sala de Arte Sacro, la imagen de Santa Águeda de Catania, virgen y mártir del siglo III, que mostraba sus pechos cortados y puestos en una bandeja, como símbolo de la relación de los senos con el pecado. Más allá de esto, las imágenes de santos y vírgenes eran representaciones que, en primera instancia, debían ser aprobadas por la Iglesia y, de igual forma, no debían incluir manifestaciones corporales como senos o volúmenes cuestionables.

Anatómicamente, sólo se permitía trabajar en la figura semidesnuda de Jesús crucificado; fue ahí que los artistas imagineros volcaron toda su creatividad. Muchas de las

${ }^{3}$ Camerín con la imagen de la Virgen rodeada por la Santísima Trinidad. S.F. MNCR I.G.B 256. Colección MNCR 


\section{Figura 5}

Santos desvestidos. Iglesia de Pozos de Santa Ana (2013)

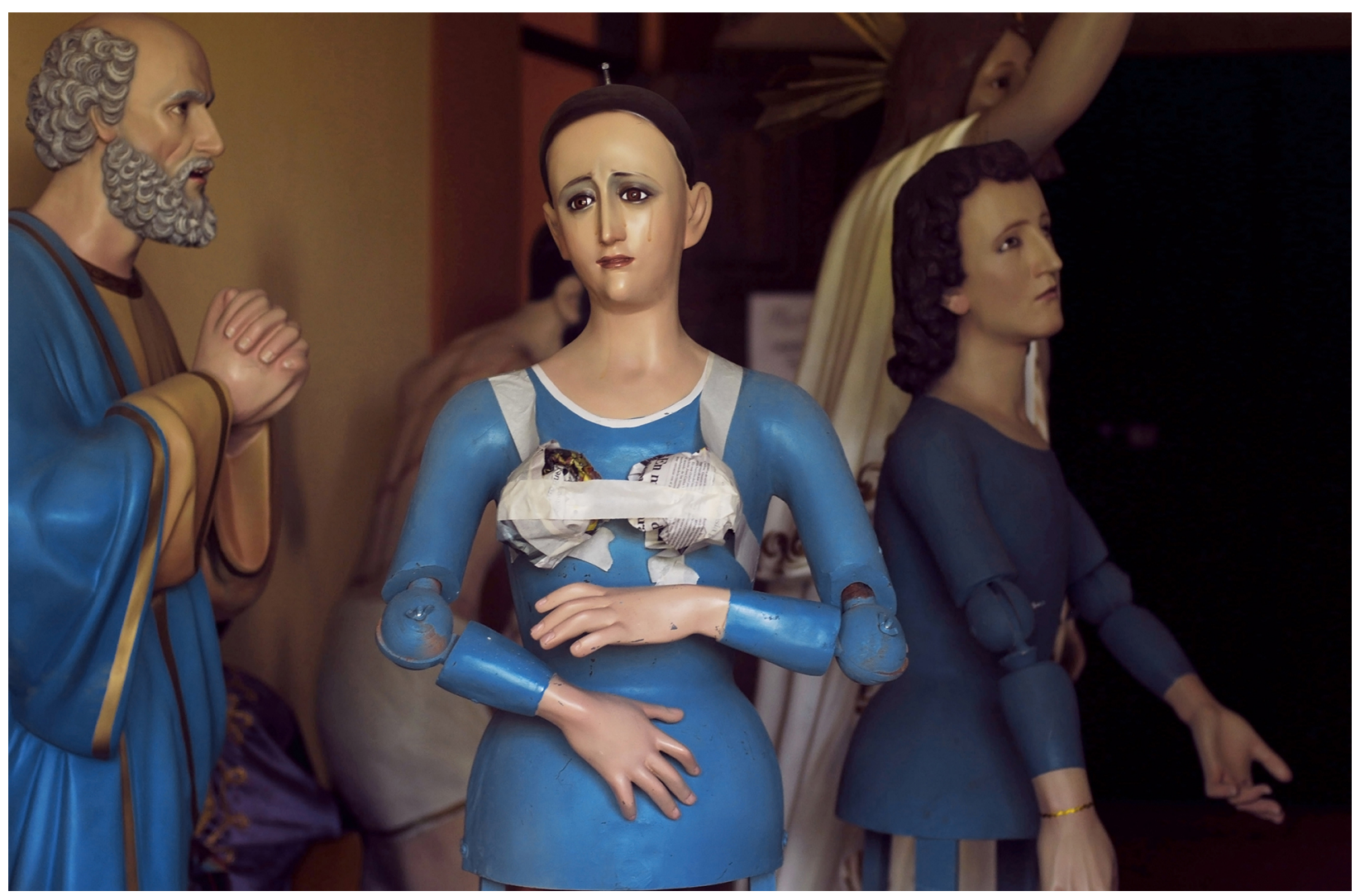

Fuente: Alejandra Guzmán

representaciones eran de estuco, asexuadas, y habían sido transformadas, dependiendo de lo que se requiriera. Un San Juan con rasgos sumamente femeninos, o una Virgen, dependían del ropaje o de los accesorios y no de su anatomía. Como lo demuestra la imagen de Alejandra Guzmán, esta técnica sigue siendo utilizada hoy día, donde con una simple cinta adhesiva se le "agregan senos" a un San Juan, quien pasa como por acto mágico a ser Magdalena o Santa Marta; en este sentido, son santos, por decirlo de alguna manera, "transformistas" (Fig. 3).

Esto no es de extrañar, puesto que desde el Concilio llamado de la Contrarreforma -el cual se realizó primeramente en Mantua en $1537 \mathrm{y}$, de forma posterior, en Trento en 1545- se promulgó un decreto sobre las imágenes sagradas y sobre cómo era la forma correcta de manejar toda la iconografía y las 


\section{Artículos}

representaciones religiosas, en general. En 1563, durante la sesión XXV del Concilio, se adoptaron importantes decisiones en cuanto al culto de las imágenes. La Iglesia Católica se pronunció, dictaminando que "El concilio de Trento prohíbe toda imagen que sea inspirada en el error, que [...] pueda inducir a engaño a la gente sencilla: quiere que se evite toda impureza, que no se ofrezcan imágenes de aspecto provocativo..." ${ }^{4}$ (1653, p.2) (Concilio de Trento. Sesión XXV. La invocación, veneración y reliquias de los santos y de las sagradas imágenes,1563).

El cuerpo desnudo fue entonces prohibido por las restricciones de la Iglesia Católica. Por eso, es tan importante la ruptura que se da con personajes como José María Figueroa Oreamuno (1820-1900) que, a mediados del Siglo XIX, irrumpe con una manera diferente de pensar y, por supuesto, choca de frente con todas las normativas sociales de la época. Figueroa fue además un cronista de la historia costarricense y en el conocido Álbum de Figueroa (1900) ilustra la vida de las comunidades indígenas, en el que incluye dibujos de indígenas desnudos, mapas, genealogías, fotografías, etiquetas y diferentes crónicas de los sucesos que se habían dado en la Costa Rica, y sobre todo en Cartago, durante la época de la Colonia. Personaje además inquieto, Figueroa se vio involucrado en una gran cantidad de acontecimientos políticos por los que tuvo que huir del país, y eso le permitió desarrollarse en el oficio de cartógrafo.

En 1843, José María Figueroa es juzgado en la Ciudad de Cartago por sus hojas sueltas

\section{Figura 6}

José María Figueroa. Dibujo a lápiz (1843).

Fotografía S. Vargas.

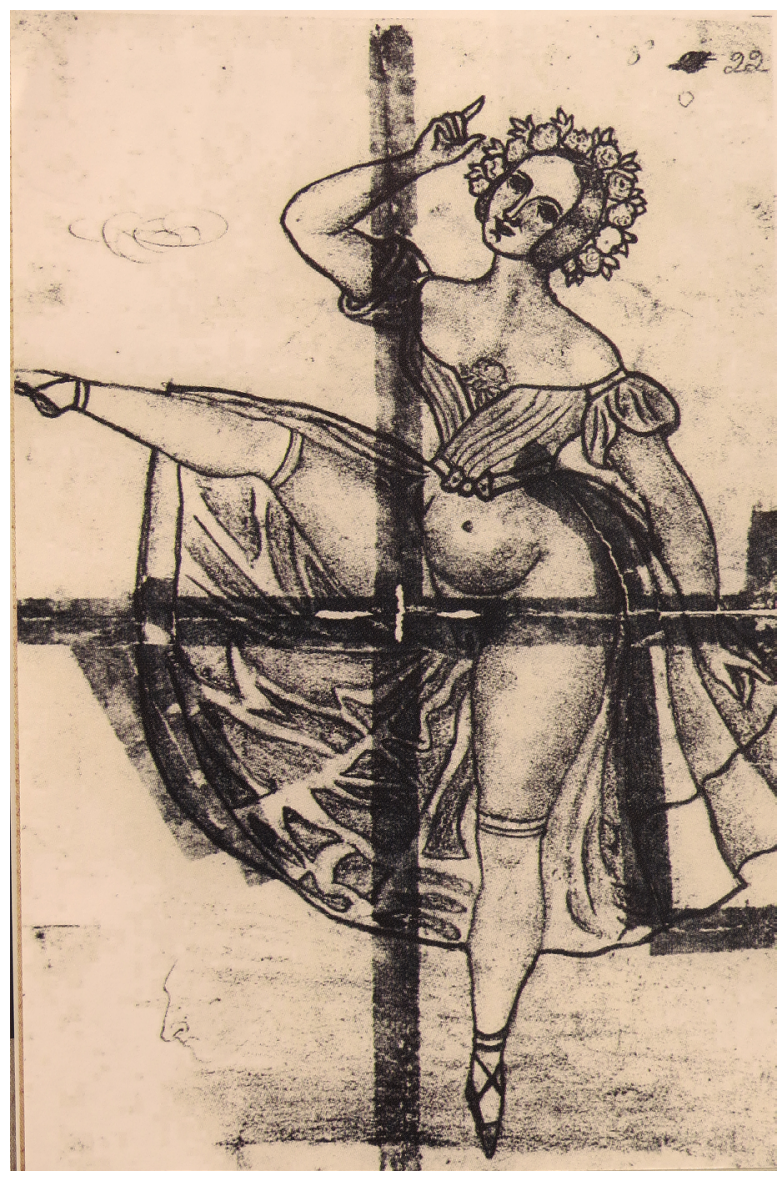

Fuente: Archivo Nacional de Costa Rica

${ }^{4}$ Concilio de Trento, sesión XXV, La invocación, veneración y reliquias de los santos y de las sagradas imágenes (1653, p.2). Biblioteca Electrónica Cristiana. 
con textos que criticaban fuertemente a personajes públicos y por sus dibujos inmorales. En el expediente se afirma “[...] que Figueroa andaba mostrando al público unas láminas obscenas o figurando unas tales Alfaros de Cartago, semidesnudas, lo que hiere gravemente la delicadeza de éstas y atenta contra la vindicta pública." (ANCR, Jurídica, No. 137, 1843).

El dibujo que sobrevive (Fig. 4) es parte del extenso documento que se conserva en el Archivo Nacional, rústicamente reparado con cinta adhesiva. Este muestra a una mujer esbelta en la postura clásica del baile de cancán -con su pierna abierta y su vulva expuesta- el cual se había vuelto famoso en la Francia de 1840 y al que se consideraba obsceno y escandaloso. En los cabarés las mujeres salían con bombachas, pero en los bares de los barrios bajos mostraban su pubis desnudo. No es de extrañar que Figueroa pudiera haber tenido acceso a imágenes parecidas, pues era el tipo de estampas eróticas que circulaban en la época y que se hicieron muy populares antes de la aparición de las imágenes fotográficas.

Se ha comprobado en los cuadernos publicados en el 2010 por la Fundación Escuela
Para Todos, que Figueroa tuvo acceso a láminas y dibujos de J. J. Grandville ${ }^{5}$ y de Jules Worms ${ }^{6}$, las cuales motivaron la sátira política a través de la antropomorfa de personajes políticos, por lo que se sabe que alguna de estas estampas de cancán llegó a sus manos. En el documento original del juicio Figueroa, nunca reniega de su autoría. Lo que sí es importante destacar, en definitiva, es el atrevimiento de la imagen para la tradicional provincia de Cartago, de ese momento.

Más adelante, en su Cuaderno Rojo aparecen varias reminiscencias eróticas (Porras, 2012. pág. 136) que son utilizadas como herramienta crítica de los acontecimientos políticos de la década de 1870 . En la imagen se satiriza sobre una "máquina para patentar" médicos, políticos y diferentes profesionales. Los personajes son pasados por una máquina moledora que procesa gente común y deja salir por el otro extremo a profesionales, mientras otros, atrevidamente desnudos para la época, son parte del engranaje o dejan salir ventosidades por sus rectos. Figueroa fue sin duda un personaje que se rebeló contra las estructuras socialmente permitidas de su tiempo, por medio de sus dibujos o sus retahílas.

\footnotetext{
${ }^{5}$ J.J. Grandiville. (1803-1843) Nombre real Jean Ignace Isidore Gérard, dibujante francés, que se popularizó por sus dibujos de caricaturas satíricas de personajes con cabezas de animales. Sus Dibujos tuvieron gran divulgación por medio de las litografías en todo el mundo. Su obra fue rescatada por los surrealistas quienes lo consideraban uno de los precursores del movimiento.

${ }^{6}$ Jules Worm (1832-1914) Pintor y dibujante francés, se inició trabajando en periódicos satíricos de la época y especializándose en litografía, luego se dedicaría a la pintura.
} 
Artículos

Veinte años después en 1863, Fadrique Gutiérrez (1847-1897) quien fuera escultor, ingeniero y fotógrafo, entre muchas otras cosas, talla sobre piedra la escultura Eva (Fig. 5), conocida como Venus, una mujer con el torso desnudo "[...] considerado hasta la fecha como el desnudo más antiguo que se conoce en el país y por esto, un hito en la historia del arte costarricense" (Rojas, 1997).

La obra de rústica tallada generó un escándalo en la sociedad conservadora herediana. Por muchos años permaneció en los jardines de la antigua Escuela Normal Superior de Heredia, hasta que fue removida por vandalismo y hoy se conserva en la colección del Museo Nacional. La obra, aparentemente, fue parte de una fuente que bordeaba los Tanques Municipales de Heredia y que al demolerlos fue también destruida. Es muy probable que su Neptuno (1863) que también sobrevive en la Municipalidad de dicho cantón, haya sido igualmente parte de este conjunto, el cual se calcula estaba compuesto por unas quince o dieciséis figuras. Estos temas, denominados paganos, fueron abordados por muy pocos artistas, la mayoría escultores.

En ese tiempo los artistas de occidente estaban destinados a trabajar solo el tema religioso; el caso de este país no fue la excepción y aunado al hecho de la ausencia de escuelas de arte, el proceso fue aún más lento. De forma precisa, por lo anterior, resulta interesante esta pieza, que se sale de todas las normativas del momento: Gutiérrez se atreve a esculpir una mujer con el torso
Figura 5

Eva (1863)

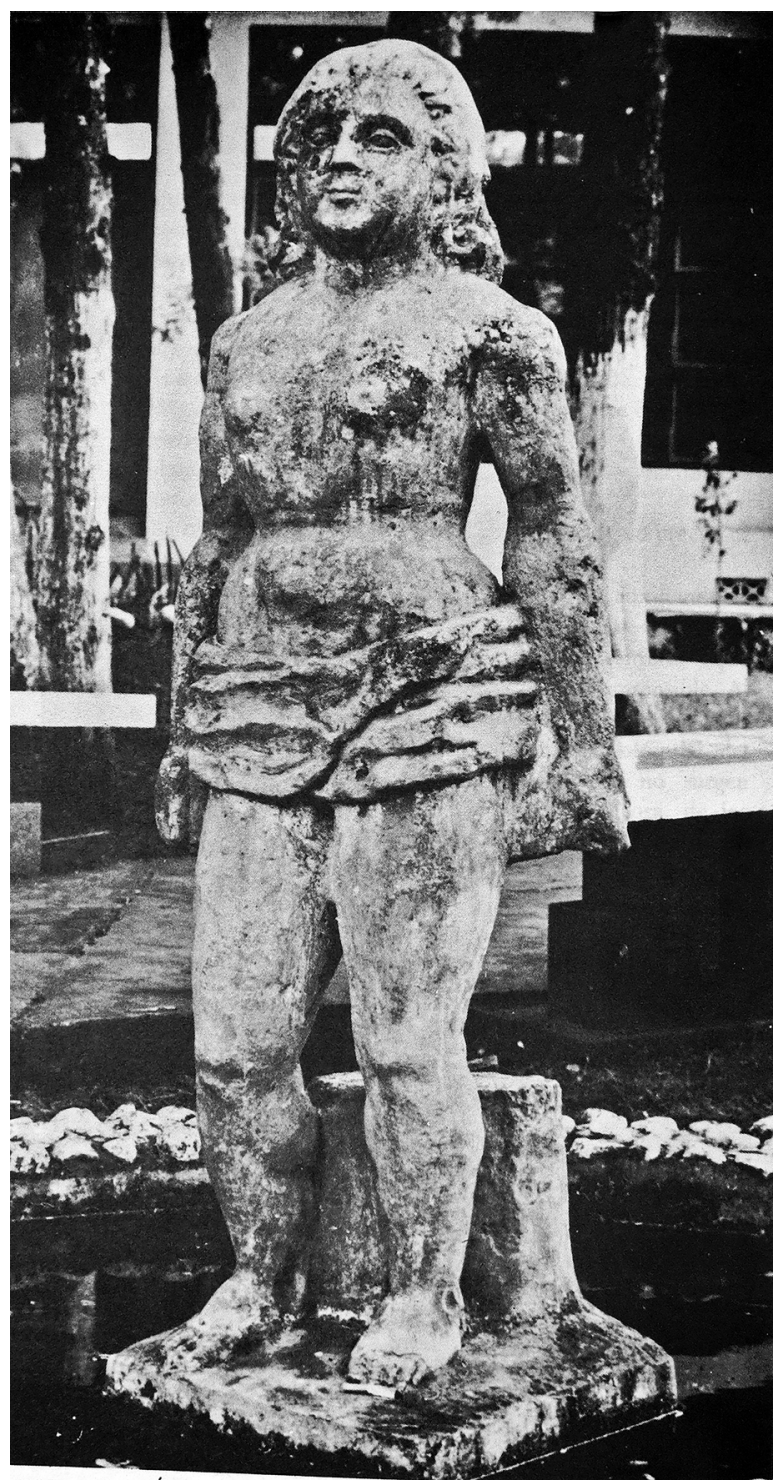

Fuente: Fadrique Gutiérrez

desnudo y con una pequeña tela que apenas cubre su pubis. La obra, según las crónicas de la época, generó mucha incomodidad. 


\section{Figura 6}

Thomas H. Penny. (1892). Detalle tarjeta postal

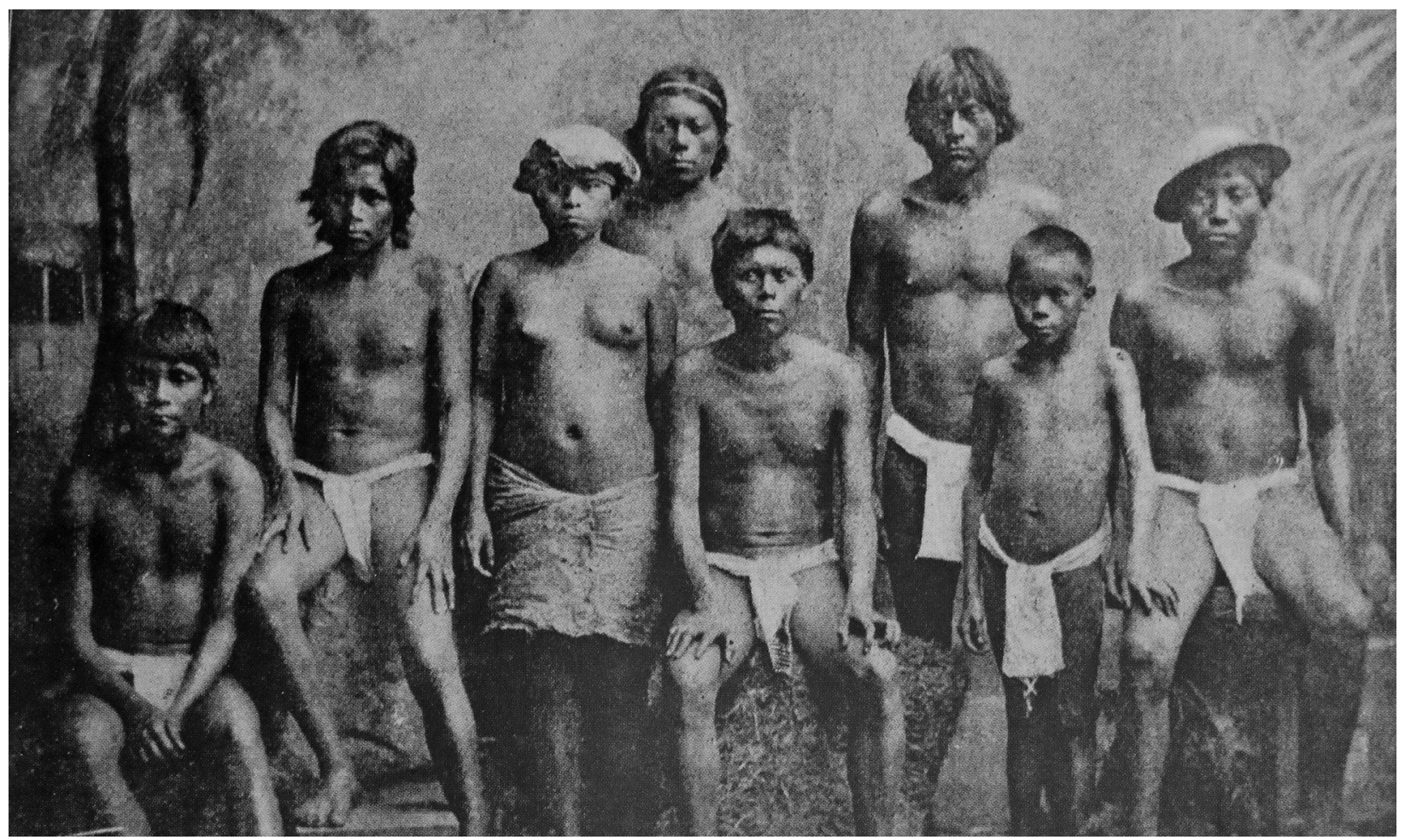

Fuente: Colección S. Vargas.

Para ese tiempo, hacia $1860^{7}$, ya se habían establecido en Costa Rica los primeros estudios fotográficos, con la llegada de profesionales extranjeros como Lorenzo Fortino y Eduardo J. Hoey. Sin embargo, además del retrato a cuerpo entero o tres cuartos, no se tienen registros de fotografías de desnudos en ese período. Lo que sí se realizó fue la fotografía de carácter etnográfico o de "tipos", que fueron vendidas a empresas en Europa y Estados Unidos como tarjetas postales. Coleccionar al "otro" se volvió una moda en la época. Entre estas postales se encuentran muchísimas imágenes de indígenas. Eran fotografiados como sujetos etnográficos divididos en tres categorías: imágenes antropométricas basadas en el sistema de T. H. Huxley y John Lamprey; ${ }^{8}$ fotografías in situ en la que el

\footnotetext{
${ }^{7}$ Vargas Alvarado, Sussy. 2004. La Mirada del Tiempo: Historia de la Fotografía en Costa Rica 1948-2003.

${ }^{8}$ Inventan un procedimiento de medición antropológica y fotografía hacia 1860.
} 


\section{Artículos}

investigador era parte del entorno, y producciones de retratos llevados a tarjetas postales.

Como ejemplo de lo anterior, destacan las imágenes de los hermanos Paynter en la zona de Talamanca, así como las fotografías de Fernando Zamora a los malekus en 1909, y las representaciones documentadas por Amando Céspedes Marín a los Guatusos, en 1923. De forma particular, resulta interesante la imagen de Thomas H. Penny ${ }^{9}$ (Fig.6), la cual se distribuyó como tarjeta postal en 1909; aquí, es posible observar cómo el fotógrafo cubre con una tela la desnudez de los varones, mientras que la joven aparece con su atuendo natural y sus senos descubiertos.

[...]estas fotografías comenzaron a coleccionarse ávidamente y por distintos públicos, en una especie de consumo compulsivo de exotismo que comenzó a apoderarse de estos ciudadanos y ciudadanas, quienes se maravillaban por la alteridad radical de los otros, o bien, saltaban de espanto frente al salvajismo de piel morena que estas fotografías traían hasta sus ojos. Pero este mismo público, en un momento de gran represión sobre la sexualidad, le da un uso oblicuo a esas imágenes, quizás en un ámbito más privado; ya que sobre todo cobra importancia el sentido erótico. Con esto, se entra en un ámbito distinto, de deseo, de choque con las imposiciones morales, incluso legales. (Revista Chilena de Antropología Visual, 2002, p. 5)

Estas imágenes eran catalogadas con la etiqueta de "interés antropológico"; sin embargo, más allá de esto, poseían connotaciones relacionadas con el erotismo y el deseo sexual. Se solía ver la desnudez de los indígenas como algo que fascinaba, pero a la vez perturbaba. Las imágenes de desnudos, fuera de su función, eran clasificadas de "obscenas" o "indecentes"; así, dichas imágenes de aparente interés antropológico, de igual forma, se consideraban demasiado molestas para ser contempladas. Por lo que "[...] el término cuerpo era demasiado vulgar como para ser citado en público." (Ewing, 1999, p.23).

El siglo XIX, excepto por Figueroa Oreamuno y Fadrique Gutiérrez, va a estar regulado por imágenes fundamentalmente religiosas realizadas por imagineros; dibujos o litografías reproducidas en periódicos y revistas, y fotografías de retratos. Solo a finales del siglo XIX - de forma particular en la década del noventa-, se darán varios acontecimientos que son importantes de señalar. En primera instancia, se resalta la llegada de compañías teatrales al país, hecho que generó las primeras manifestaciones de censura; tal y como lo señala Patricia Fumero, esta

\footnotetext{
${ }^{9}$ Existe una reproducción de esta tarjeta postal en la colección del Sr. Tomás Dueñas, que incluye una imagen de una casa cónica y la misma está firmada por los Hermanos Paynter, la primera vez que se reproduce aparece en la Revista Páginas ilustradas de 1909 con la firma a mano de Thomas Penny. La placa original se conserva en la colección del Museo Nacional pero el deterioro no permite ver la firma. (Placa original gelatino sobre vidrio en custodia del MNCR. No Inv. 10098)
} 
censura teatral “[...] se aplicaba, de manera indirecta, mediante la presión del público, $y$, de manera directa, con el nombramiento de censores o tribunales de censura (Fumero-Vargas, 1996, p.176)."

Los medios impresos y el Eco Católico fueron parte de esta pauta, que se transformó en un termómetro para medir el recato y la moral de los "otros". En otros ámbitos, la fundación de la Escuela Nacional de Bellas Artes y la inauguración del Teatro Nacional, en 1897, conllevaron a una vuelta al arte clásico en el que el cuerpo se miraba a partir de estos referentes. Lo clásico denominaba el buen gusto en las clases de alta sociedad de la época y, en medio de esto, la representación del cuerpo era permitida; las esculturas clásicas y el método Julien de copia de estampas se convirtieron en el modo de acercarse al arte culto. Esa misma desnudez llega a los medios impresos, a los cementerios, a las viñetas que acompañan los títulos académicos y oficiales, a la mampostería de los edificios y, desde luego, al Teatro Nacional.

Tanto las esculturas e imágenes traídas por Tomás Povedano como sistema de enseñanza para la Escuela Nacional de Bellas Artes, como sus propias obras -tanto aquellas realizadas para la inauguración del Teatro Nacional como las colocadas más adelanteson imágenes en las que se puede apreciar el cuerpo; no obstante, fueron censurados los genitales tras una hoja de parra, se suprimieron los pezones y se anuló cualquier otra señal de erotización. El Medallón de la
Abundancia (Fig. 7) muestra una figura de un Mercurio casi andrógino, en un cuerpo asexuado. Resulta interesante destacar aquí las figuras zoomorfas de la decoración de los muebles del foyer, en las que seres con pechos firmes y pezones erectos se esconden bajo la cara de personajes bestiales. Más adelante, con la llegada de bailarinas famosas y exóticas - como la célebre, amada y odiada Tórtola Valencia, la cual encarnó un hito de la sensualidad y la ruptura de la moral-, se generó mucha controversia en la época. Es entonces que en las estampas donde aparecen estas mujeres, así como cualquier imagen que se acercara a esas características, se consideraba como un objeto hiriente para la moral del momento.

\section{Figura 7}

Tomás Povedano. (1910). El Medallón de la abundancia. Teatro Nacional

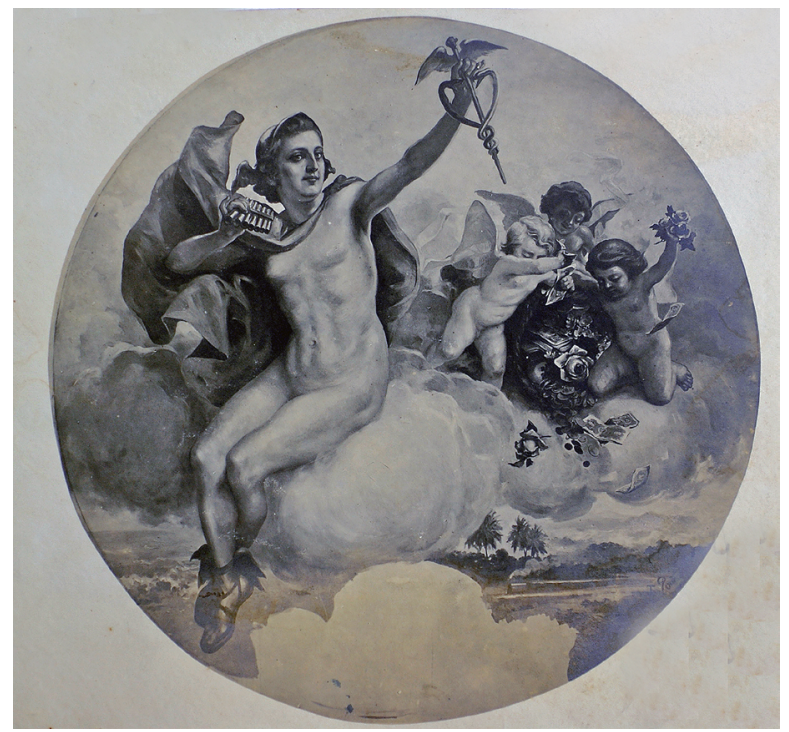

Fotografía por S. Vargas 


\section{Artículos}

En el Boceto de la República de Costa Rica, se observa de forma clara, la censura que ya existía con respecto a las llamadas "imágenes indecentes". En el párrafo sobre "Mercaderías de importación prohibida", se cita lo siguiente: "Queda prohibida la introducción de: a) Esculturas, pinturas, vistas, fotografías, litografías obscenas, lo mismo que libros impresos, manuscritos contrarios a la moral y las buenas costumbres" (Boceto de la República de Costa Rica, 1910)”.

Contrariamente, la litografía permitió la divulgación de estampas eróticas prácticamente desde su invención, en 1796, la cual se incrementó con la aparición del daguerrotipo en 1839, у ya “[...] para 1840-1844, surgen en París las primeras fotografías de carácter íntimo, despertando el apetito sexual, el morbo y el deseo privado" (William, 2000). Estas imágenes mostraban, a diferencia de las estampas, cuerpos reales con todos los elementos que habían sido censurados en las láminas dibujadas o pintadas: vello púbico, pezones, vaginas, penes y penes erectos. La gran mayoría eran anónimas, pues era sumamente riesgoso para un fotógrafo firmar la imagen con su nombre; en algunos países podía acarrear hasta la cárcel. Además, gran parte de los modelos que posaban para los retratos eran prostitutas y vagabundos. Cabe destacar que estas fotografías adquirieron una enorme repercusión; en una sociedad acostumbrada a reprimir sus apetitos, de forma inmediata, surgieron los protectores de la moral.

Así pues, se dividió la fotografía de desnudo en fotografía de desnudo artístico, que respondía más a cánones clásicos, donde la imagen se centraba en la forma y no se mostraban detalles corporales; la imagen erótica, la cual se centraba en la belleza y, a veces, aparecían algunos detalles corporales como pezones o vello púbico; $y$, finalmente, las impúdicas u obscenas (que serían más adelante renombradas como pornográficas), en las que se muestra el cuerpo y sus genitales de manera directa, así como relaciones coitales.

\section{Figura 8}

Sin autor. (aprox.1910). Fotografía erótica

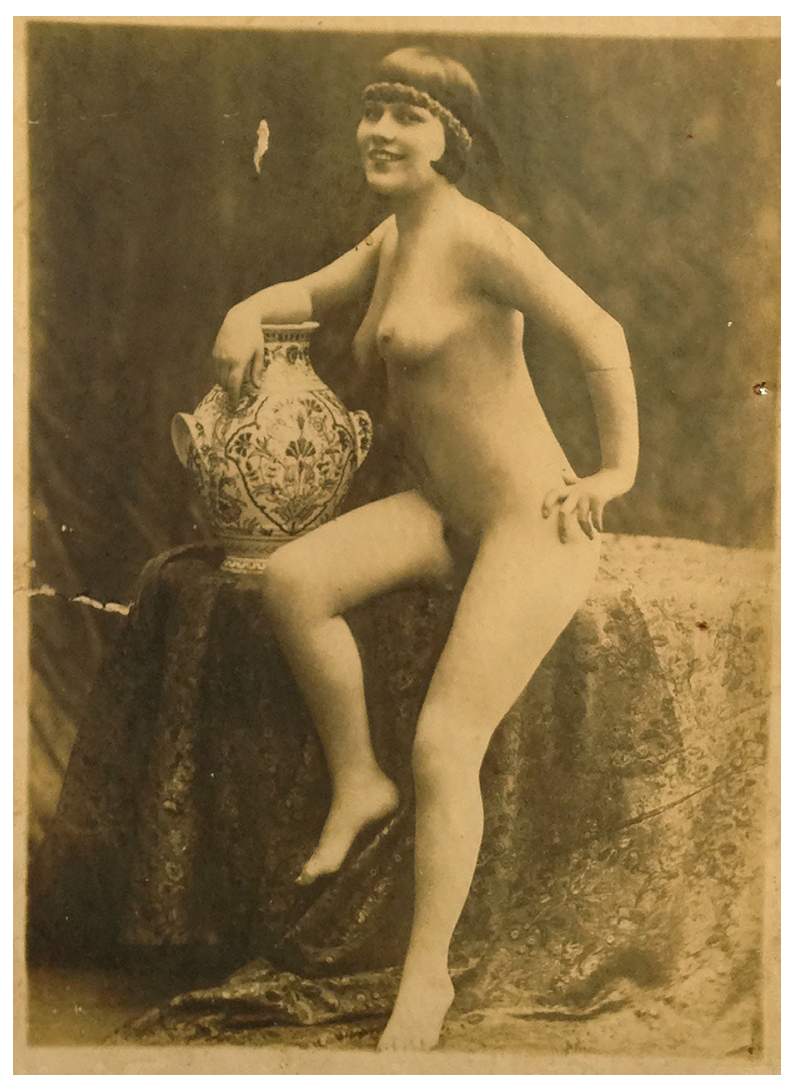

Fuente: Colección de S. Vargas 
De cualquier manera, en una sociedad conservadora como la costarricense, imágenes que sólo insinuaran una leve intimidad de pareja o mostraran parte del cuerpo, de manera inmediata, eran consideradas faltas a la moral. Muchas de estas imágenes aún se conservan en el país y se divulgaron por medio de tarjetas postales que eran, además, coleccionables. Se cree que la mayoría fueron obtenidas en viajes realizados al exterior, sobre todo a París, que era uno de los lugares de mayor divulgación de imágenes de este tipo.

De forma paralela, en noviembre de 1928 se inaugura, en el Teatro Nacional, la

\section{Figura 9}

Gómez-Miralles, Manuel. (1928). Exposición de Arte Argentino. Detalle fotografía N. 4979. Reproducción por contacto directo S. Vargas.

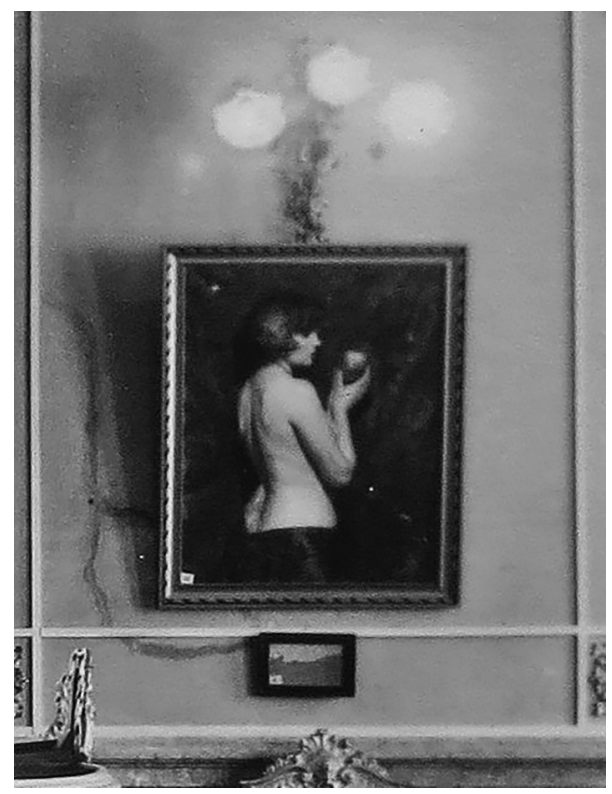

Fuente: Archivo Teatro Nacional
Exposición de Arte Argentino, organizada por el entonces embajador Don Enrique Loudet. Los salones del foyer se llenaron de aproximadamente 50 obras pictóricas y 20 esculturas de diferentes autores. Según las crónicas de la época más de seis mil personas visitaron la exposición, entre ellos los más destacados artistas de ese tiempo.

Dentro de las placas originales que se conservan en los archivos del Teatro, realizadas por Manuel Gómez Miralles, destaca una en la que se contempla colgada en la pared: un semidesnudo de mujer con una manzana en la mano. Dicho cuadro es de autor desconocido, sin embargo, destaca por su gran realismo, tomando en cuenta que la gran mayoría de las obras y los artistas que se mostraron en esa ocasión pertenecían o tenían gran influencia del impresionismo. En esta, una mujer muestra su espalda descubierta mientras que entre sus manos sostiene una manzana: inevitable relación con el mito de Eva. En las notas de prensa se habla de los paisajes, de la belleza de las esculturas, pero nadie menciona este desnudo, el cual -luego de revisar las crónicas y las publicaciones de la época- es el único desnudo que se presenta en la exposición. Resulta también importante mencionar que varios de los artistas argentinos que mostraron obra, trabajaron el desnudo artístico; no obstante, la mayoría de las obras exhibidas fueron paisajes, retratos y escenas campestres.

La mencionada exposición daría la pauta para iniciar las exposiciones de arte nacional, que se realizaron en el Teatro Nacional 


\section{Artículos}

de 1928 a 1937. En esos años, según las cifras recopiladas por Eugenia Zavaleta en su investigación (2004), muy pocos presentaron el desnudo como tema. En nueve años sólo 15 artistas lo abordaron; de ellos trece fueron varones y únicamente dos mujeres: Lollita Zeller de Peralta (1903-1990), con una pintura que representaba una escultura clásica a la que tituló Venus del Baño (1936) y Lilly Artavia (1905 aprox. - 1982 aprox.) quien, aparentemente, exhibió desnudos pintados de modelo directo en 1930, 1935 y 1936; de acuerdo con Zavaleta, muchas de las obras "[...] que presentó en varios de los certámenes, debieron sobresaltar a la sociedad y convertirla temáticamente en una vanguardista" (2004, p.33). Artavia fue no sólo una artista que se atrevió a tratar temas poco aceptados en su época, sino que se destacó -al igual que otras mujeres, como Yolanda Oreamuno y Eunice Odiopor romper con las normativas impuestas a las féminas en su momento. Su obra y su vida de forma necesaria, deberían ser abarcadas en un trabajo serio de investigación.

Continuando con el tema, el desnudo no fue un tema muy trabajado en los Salones de las Exposiciones Nacionales. Cuando este se mostraba, trataba de no ser demasiado realista, como en el caso del desnudo femenino presentado por Francisco Salazar en la exposición de 1935. Como ejemplo, Zavaleta (2004) justifica la escasez de desnudos por medio de un certamen convocado por los padres capuchinos en 1924, en donde los tres temas posibles con los que se podía participar eran "asunto religioso en general", "asunto especial de carácter franciscano" y "asunto de tema profano o no religioso, con tal de que no se exhiban al desnudo" (Diario de Costa Rica, 1924, p.11). Nuevamente, esta interesante referencia habla un poco del contexto en que el tema del cuerpo era tratado por una sociedad sumamente tradicional y conservadora y en el cual la Iglesia Católica era quien regulaba la forma de vestirse y de comportarse.

Esta visión debió provocar inhibiciones en los artistas para representar el desnudo. Los cuerpos femeninos fueron expuestos con cierto recato y sin exaltar sus atributos sexuales. Por ejemplo, José Francisco Salazar se inclinó por la idealización, Francisco Zúñiga por la simplificación en Fecundidad, recurso también inspirado por las tendencias de vanguardia, y José Manuel Caballero veló la figura de su musa. (Zavaleta, 2002, p.184)

No obstante, a finales de los años treinta se dio un manejo del cuerpo más sensual y erótico. Obras de mujeres absolutamente corpóreas, voluptuosas y sensuales fueron parte de los trabajos realizados por Manuel de la Cruz González (1909-1986), o en los dibujos y pinturas elaboradas por Max Jiménez Huete (1900-1947), desde mediados de los años veinte hasta su muerte. Francisco Zúñiga (1912-1998) también explora el cuerpo y el tema del deseo. Ya en sus primeras obras, como por ejemplo Amantes (dibujo a lápiz de 1935) (Consejo Nacional para la Cultura y las Artes, 1994, p.59), se observa una tímida representación de la intimidad y una representación más erótica y telúrica del cuerpo femenino. En su discurso de ingreso a la Academia de Artes de México, en agosto de 
1987, afirmaba refiriéndose a su trabajo con los cuerpos de las mujeres indígenas: "Relaciono todo esto simbólicamente con lo geológico, lo terráqueo del origen, más aún, lo erótico" (INBA, 1994, pp. 43-44).

Importante resulta el quehacer de Juan Manuel Sánchez (1907-1990), escultor que toma como una de sus temáticas preferidas

\section{Figura 10}

Juan Manuel Sánchez. (s.f.). Dibujo a pluma

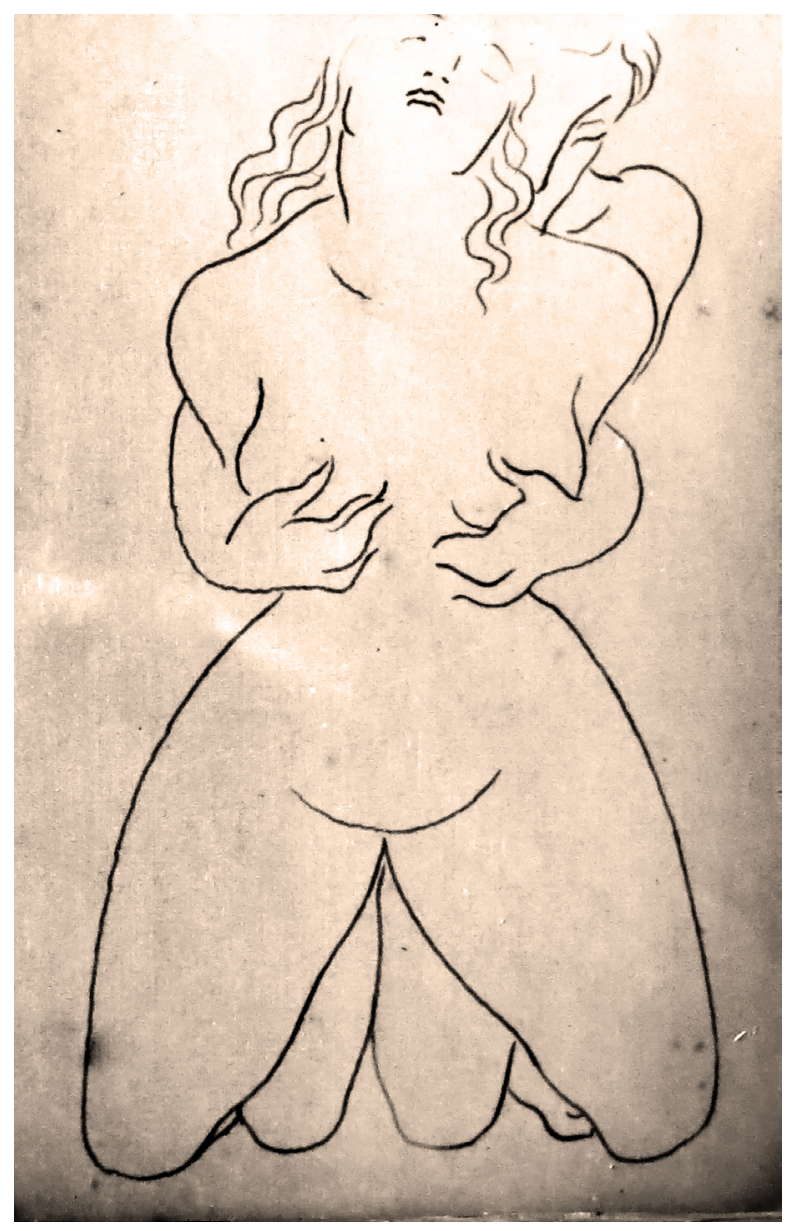

Fuente: Colección MAC el cuerpo femenino, generando imágenes de gran sensualidad y erotismo. La hermosa talla sobre madera Euforia (1938), remite no solo al cuerpo como forma o como un simple estudio, sino que utiliza la línea, lo voluptuoso y la curva, para entregar una obra llena de sensualidad.

No obstante, la obra más interesante en este campo de Sánchez no son sus esculturas, sino sus prácticamente desconocidos dibujos eróticos. Su compañera de vida, Berta Solano, tuvo la visión de donarlos, junto con el resto de las obras que estaban en su poder, al Museo de Arte Costarricense en 1998. Los dibujos realizados sobre diferentes muestran escenas de la intimidad de una pareja y, por los rasgos, probablemente la del mismo autor y su amada esposa. Cabe resaltar que cuando se ha mostrado parte de la colección no se han incluido ninguno de estos dibujos.

Muy significativo es el papel que cumplió la profesora Margarita Bertheau (1903-1975) quien introduce en 1942, el desnudo con modelo en la Escuela de Bellas Artes, 45 años después de fundada. Dicha implementación recibió una gran oposición por parte de maestros y estudiantes. Finalmente, Teodorico Quirós, quien en ese momento desempeñaba el cargo de director de la Escuela, lo aprueba, generando un cambio importante en la Academia. La misma Bertheau es una de las que trabajan con modelo directo dejando retratos de gran belleza y erotismo, donde personajes como Eunice Odio o Yolanda Oreamuno, sus íntimas amigas, posan para ella, en un acto de complicidad y de irreverencia social. 


\section{Artículos}

Ya para inicios de la década del cincuenta, Álvaro Herrera junto con Alfonso Esquivel Lang trabajaron como pioneros de la fotografía médica en el Hospital San Juan de Dios. Utilizaban el estudio de Aubert, ubicado en San José, y el de Francisco (Paco) Urbano, ubicado cerca del Correo Central, para experimentar con el tema del cuerpo. De acuerdo con Andrea Liggett y su hijo Arturo Herrera L. “[...] ellos se aventuraron a realizar otro tipo de fotografía; el desnudo artístico. Las fotografías las realizaban sólo para ellos y como modelos posaron algunas enfermeras del San Juan de Dios, invitadas por Alfonso Esquivel"10 (comunicación personal, 26 de mayo, 2004).

Las imágenes (Fig. 11) fueron realizadas a escondidas y los nombres de las modelos quedaron en el absoluto anonimato. Hubo una decisión clara y consciente por parte de los autores de no mostrar sus imágenes; en primer lugar, por el nombre que ya tenían en la fotografía médica y, en segundo lugar, porque el entorno social no estaba preparado. Dichas fotografías, las cuales nunca han sido mostradas -exceptuando las de Herrera- se encuentran hoy desaparecidas. El trabajo de ambos se posiciona como un referente importante de los estudios sobre el tema en el país.

Para 1973, Víctor Vega realiza varios desnudos femeninos con una fuerte carga erótica, poseedores de una búsqueda del manejo de la iluminación como lenguaje dramático. En 1977, Arturo Herrera Liggett aprende el oficio de la fotografía de su padre Álvaro Herrera y
Figura 11

Sin título. (1952)

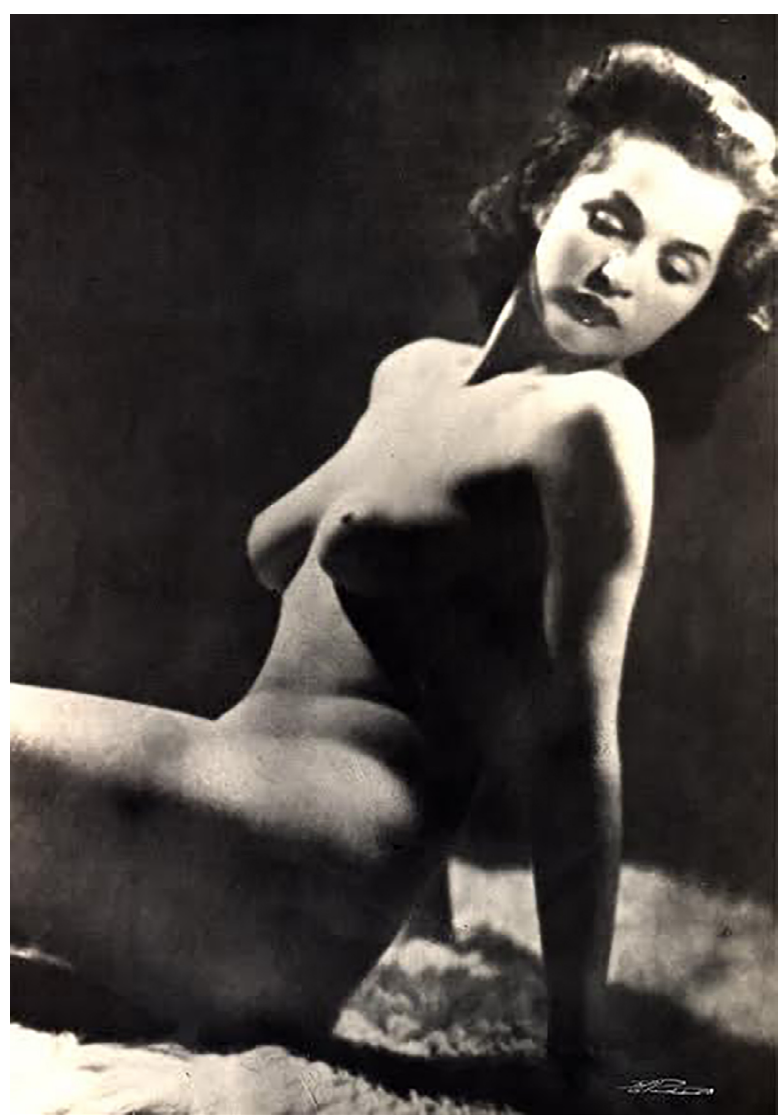

Fuente: Archivo propiedad Familia Herrera Liggett

entra, desde su juventud, al tema del desnudo. Será él quien realice lo que se conocerá como la primera muestra con el tema del desnudo en Costa Rica, y no sin antes pasar por el filtro de la censura, pues el montaje de su exposición en la Escuela de Estudios Generales de la Universidad de Costa Rica tuvo muchos detractores. Fue la intervención de sus maestros,

${ }^{10}$ Entrevista realizada a Andrea Liggett y su hijo Arturo Herrera L. (26 de mayo 2004), por la autora. 
Figura 12

Xiomara (1975)

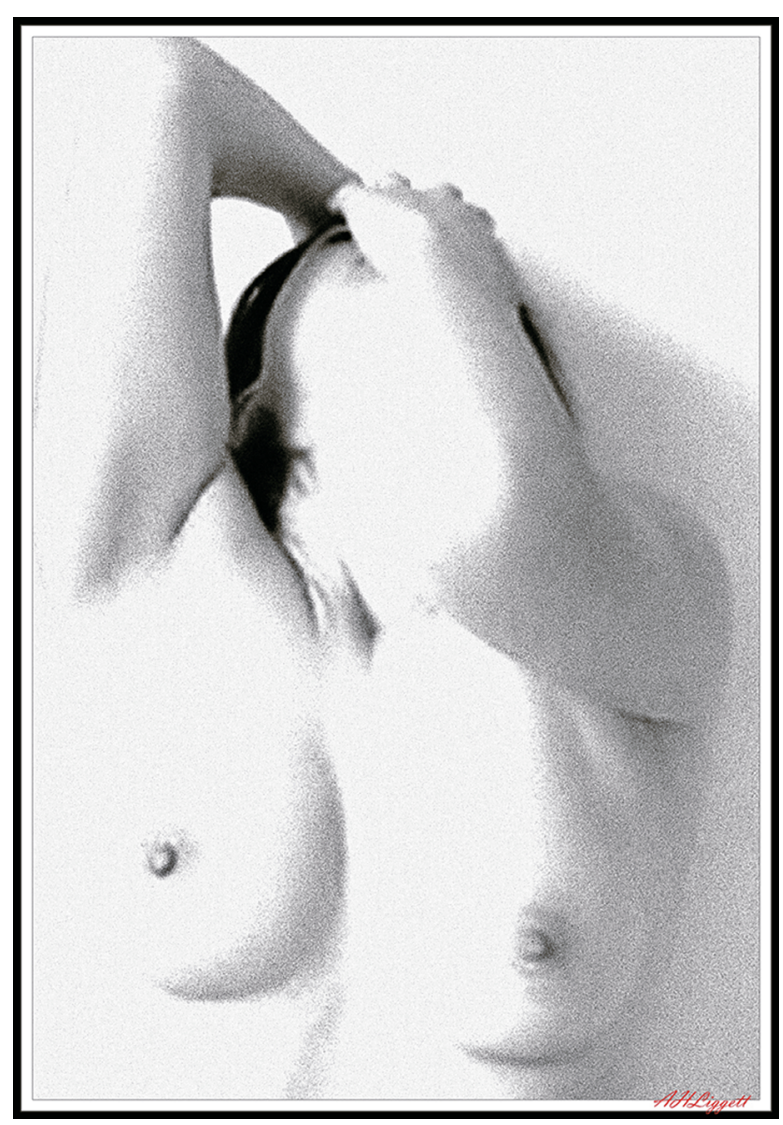

Fuente: Arturo Herrera

Francisco Amighetti y Adrián Valenciano, lo que permitió que la exposición se llevase a cabo. Los cuerpos en las imágenes de Herrera son alegorías a la belleza del cuerpo femenino por medio de la fragmentación (Fig. 12).

\section{Apropiaciones (1980-2015)}

Analizando las tres últimas décadas de la fotografía y el arte en Costa Rica con respecto a los límites del tema del cuerpo y las prohibiciones, es muy importante destacar el papel que tuvieron los Salones Nacionales que se realizaron entre 1984-1994, los cuales dieron un espacio muy importante a la fotografía. En ellos el tema del cuerpo encuentra su lugar y muchos fotógrafos empiezan a mostrar sus imágenes de desnudos.

En esta etapa, Fernando Acuña y Rodrigo Montoya realizaron una obra en la que el desnudo femenino es mirado desde una postura conceptual y poética. Los años noventa plantearon la particularidad del inicio en el abordaje del desnudo masculino, mayoritariamente realizado por fotógrafos varones. $\mathrm{El}$ cuerpo masculino se comenzó a mirar desde la forma, la belleza, el erotismo y la sensualidad. Ya en 1910, Tomás Povedano había realizado un estudio que denota cierta sensualidad y libertad en la pincelada, que de hecho rompe con su propio estilo y factura pictórica. La obra mal titulada Torso (Ferrero, 1986, p.181), propiedad de la familia Borrasé-Povedano, representa la cadera y glúteos de un hombre, probablemente un estudio de alguna de las esculturas clásicas de la Escuela de Bellas Artes y que, de alguna manera, antecede a estos trabajos del desnudo masculino.

El desnudo masculino, como se planteó en la exposición Imágenes de Hombres, realizada en los Museos del Banco Central a finales del 2000 y principios del 2001, no ha sido una temática del arte tan constante como en otros países. En el caso particular de la fotografía, ha sido fundamentalmente tratado por fotógrafos varones, entre ellos, el pionero Giorgio Timms, Jaime-David Tischler y Larry 


\section{Artículos}

Madrigal, siendo este último de los pocos que trabajan el desnudo masculino en color. Por el contrario, es hasta épocas recientes que algunas mujeres han empezado a abordar el cuerpo masculino como parte de una temática de trabajo para sus proyectos fotográficos.

[...] el desnudo masculino, a pesar de ser la base del estudio académico, no es frecuente en la producción plástica de nuestro país[... el emerger de las minorías en todos los ámbitos de la cultura ha provocado un surgir del desnudo en general y del desnudo masculino particularmente, y nuestro medio empieza también a despertar a estas nuevas corrientes... bajo actitudes muy variadas, la imagen homoerótica ha tomado fuerza en la representación artística de los últimos años; cantidad de artistas utilizan el cuerpo como vehículo expresivo para glorificar su belleza, reafirmar la identidad o para convertirlo en el receptáculo doliente de la discriminación por parte de la cultura hegemónica machista. (Alvarado y Hernández, 2000-2001)

El trabajo de Giorgio Timms (1947) se va a enfocar más en exaltar la belleza del cuerpo masculino. Su obra no va a ser censurada, lo cual le va a permitir participar en diversas exposiciones, tanto dentro como fuera del país. En la primera etapa, hay una castración voluntaria de los modelos por parte del fotógrafo, lo que es interesante, ya que el autor genera una especie de autocensura y elimina o esconde de sus imágenes los órganos sexuales de sus modelos. Contrariamente, en la segunda etapa, Timms presenta desnudos más directos donde los modelos muestran su cuerpo totalmente, bajo una narrativa especial en la que, en algunas imágenes, el fotógrafo se incluye como protagonista-narrador.

Larry Madrigal (1968) trabajó el desnudo masculino en color, con integración de materiales; además, incursionó en el tema de los transexuales en la ciudad de San José. A partir de un discurso en el que se apropia de los lenguajes del fotoperiodismo, irrumpe en el mundo íntimo de estas personas, en una ciudad que apenas se acostumbra a verlos en el paisaje urbano. Madrigal retrata a la comunidad trans en sus espacios de intimidad a partir de elementos simbólicos y significativos, los cuales contextualizan el entorno y le dan cierta temporalidad. El ensayo no encontró espacio para ser expuesto, pues no era un tema del que se hablara. Asimismo, otros que abordaron el tema de la transexualidad fueron José Miguel Rojas (1959), Ana de Vicente (1968) y Alexander Sanabria (2014).

A mediados de los años noventa se generaron varios movimientos alrededor de la censura del arte en Costa Rica que son importantes de destacar, ya que giraban particularmente en la desaprobación de temas, en su mayoría, sobre el hombre como eje del deseo. El primero se va a dar en junio de 1995 contra una obra escultórica llamada El triunfo del Cerdo, del artista Marco Chía, quien después de exhibir la pieza en el Museo Calderón Guardia decide mostrarla en la Plaza de la Democracia sin autorización. La obra que representaba a un hombre desnudo con su pene erecto, cabalgando sobre un cerdo mientras sostiene en 
su mano derecha una cabeza decapitada, es retirada 12 horas después por la policía municipal: "Personeros del Teatro Skené, institución al que el escultor obsequió la obra, informaron a Chía que, cuando fueron a buscarla en la municipalidad josefina, les dijeron que ya no se encontraba ahí. A la fecha se desconoce su paradero" (Campos, 1997).

Seis meses después, en diciembre de ese mismo año, se censura y se cierra la exposición Amor Sagrado y Profano (Fig. 13), de los artistas Roberto Rincón y Jonathan Webb, la cual se presentaba en la Sala de Exposiciones Temporales Fidel Tristán, ubicada en el Museo de Jade. La muestra fue aceptada por la directora en ese momento, Zulay Soto, y cerrada sin su consentimiento, debido a los comentarios de desaprobación de los visitantes. La exhibición mostraba fotografías de hombres y mujeres desnudos. La exposición fue abierta nuevamente y permaneció hasta febrero de 1996, después de que los artistas aceptaron retirar las fotografías que se consideraban más escandalosas.

[...]la noche de la inauguración no faltaron personas alarmadas ante aquella abierta exposición de la perfección física, de la ausencia de hojas de parra en los genitales, artificios autocensuras de parte de otros creadores y la muestra generó polémica. Pero ya estaba allí y había que observar también la belleza conceptual, la riqueza técnica y la pureza física de aquella galería de desnudos masculinos y femeninos donde se ofrecían escenas de individuos solitarios y también de pareja. (Fernández, 1996, p.3)

\section{Figura 13}

(14 de enero de 1996). Artículo sobre censura exposición Amor Sagrado y Profano, La Nación, Suplemento Áncora.

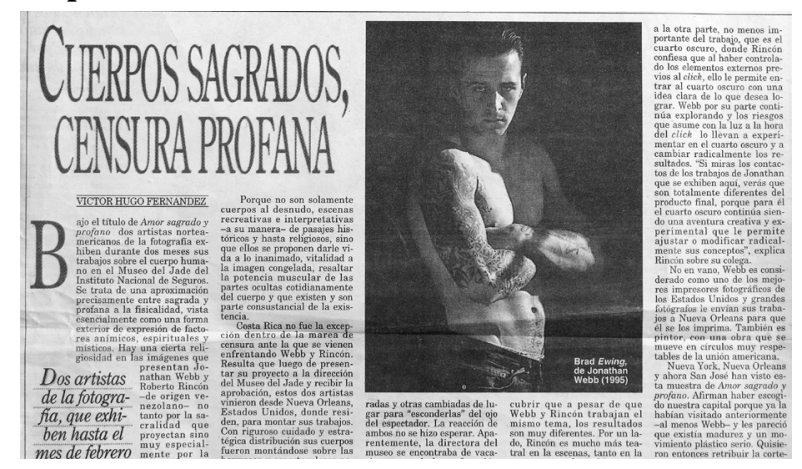

Fuente: La Nación, Suplemento Áncora.

En marzo de 1997, se censuró y se bajó la exposición El pan de los Ángeles de César A. Rodríguez, que se exhibía en la Biblioteca de la Universidad Nacional. La muestra incluía piezas donde se integraban madera, fotografía y metal que planteaban el tema de la represión sexual y la intervención de la Iglesia Católica en las acciones humanas. En la exposición se mostraron imágenes de escenas homosexuales o de minorías, además del uso de símbolos religiosos. La directora del lugar bajó las imágenes por considerarlas inmorales. Después de la intervención de las altas autoridades universitarias, la obra finalmente se pudo exponer, pero se redujo el tiempo original de un mes a una semana. Más adelante, la muestra se expuso en la Galería Dinorah Bolandi de la misma Universidad, sin ningún problema (Campos, 1997).

Posteriormente, en agosto del mismo año, se censuró, se bajó y se dañó la exposición 


\section{Artículos}

Fragmentos de un Deseo Mendicante, de Jaime David Tischler. Este acto abrió espacios importantes para la crítica y se publicaron diversos textos a favor y en contra del acto. La muestra presentaba diecinueve fotografías de desnudos, tanto femeninos como masculinos, y se montó por invitación del Departamento de Cultura del Instituto Tecnológico de Cartago. Cinco días después, la directora de la Biblioteca, que fue donde se montó la muestra, clausuró la misma debido a los comentarios escritos por los visitantes en los libros de firmas. No hubo comunicación para el artista y al bajar la muestra muchas de las obras fueron dañadas (Campos, 1997).

En la serie del mismo artista Threads of Desire (1998), se expusieron de forma directa las relaciones homoeróticas y se abrió un espacio muy importante para la fotografía contemporánea en Costa Rica. Sus cuerpos oscilan entre el deseo y la posesión física del otro. La obra abrió el espacio de lo íntimo, permitiendo al espectador pasar al recinto donde todo ocurre y haciéndolo partícipe de la consumación del placer. En 1999, Tischler recibe el Premio Nacional Aquileo J. Echeverría, por su trabajo Memoria Ingrávida y Síntomas de Identidad. La instalación fue expuesta en el Museo de Arte y Diseño Contemporáneo, y presentaba un enorme tendedero donde colgaban decenas de imágenes explícitas, en tanto que en varias grabadoras su pareja le leía poemas de amor. Este premio implicó una reivindicación de la libertad de expresión en Costa Rica y el reconocimiento a propuestas que rompían con los estereotipos sociales más estrictos.
Las sombras del fanatismo y la intolerancia en contra de sus pasadas exhibiciones, han convertido su ira inmediata en energía positiva, de la cual se vale para revolcar más profundamente dentro del alma de esta búsqueda estética. Su trabajo, evidentemente, ha tocado la trasgresión de temas de pronunciación frágil e incómoda definición. Tischler ha escogido desnudarlos más allá de su presente estado, negándose a ser detenido por las fuerzas que, bajo el estandarte de la moralidad, han tratado de impedir que el arte continúe por el sendero de la verdadera libertad de expresión. (Casares, 1998, p.4)

Por otro lado, hay un fortalecimiento del papel de las mujeres en el arte costarricense que parte desde áreas como el diseño, la plástica, la fotografía, la literatura y, actualmente, desde el cine, las cuales plantean otras miradas y relecturas del tema del cuerpo, el deseo y el placer. La mujer, a lo largo de la historia, y como motivo del arte, se ha posicionado como "la que es contemplada"; es decir, los artistas varones se han recreado en su imagen y se han apropiado del derecho otorgado por la sociedad de ser los que definen su papel. Esta ha sido la modelo, la resignada artista, la amante, la inalcanzable, la virgen y doncella pura y, en esa pureza, le ha sido vedada la posibilidad de ser la dueña de su vida, de sus deseos y hasta de su propio cuerpo. La misma ha sido el motivo de la publicidad, de los vaivenes constantes de la moda, la que vende desde una aspirina hasta una limusina. Pero ¿qué pasa cuando es la mujer la que mira, cuando es ella la que expresa su deseo por el cuerpo masculino o femenino, cuando infringe toda 
normativa permitida con su mirada? Ante esta interrogante, de acuerdo con Cao:

Las leyendas y mitos nos recuerdan lo peligroso de la mujer que mira, porque revierte el paradigma dominante [...] La medusa, que petrifica a quien la mira, es aniquilada por ella misma al recibir su mirada reflejada en el escudo de Perseo. Es el aviso de que la mujer no debe mirar, sólo ser mirada (1999, p.32).

Así, el tema del deseo femenino aparece en la literatura costarricense hacia 1948, de la mano de Eunice Odio con su poemario Los Elementos Terrestres, en el que habla sobre el deseo hacia el amado, sobre el placer desde una mirada más mística y rompe con los discursos manieristas de su época. Dicha ruptura abre paso a textos más explícitos como La estación de fiebre de Ana Istarú en 1983, el cual reivindica el placer desde el deseo carnal. Textos que, sin embargo, siguen estando vedados de los estudios sobre literatura en el país:

El sol nace en tu ingle,/ eleva con su esfuerzo/ de dios pequeñito-/ la torre de tu cuerpo,/ grave como él, y leve./ Su puño dorado/ va erigiendo tu pene/ (envidia del arcángel/ sin sexo a qué atenerse)/ hasta alcanzar la punta/ del labio donde endulzas/ tu gota de varón/ y la sostienes. (Istarú, 1983)

Adela Marín Villegas (1969), artista visual, trabaja desde finales de los años noventa con el tema del desnudo artístico, la autorreferencia a partir de la fotografía y el videoarte, siendo parte de una de las pocas

\section{Figura 14}

Adela Marín (2002-2004). De la serie: Yo como voyer.

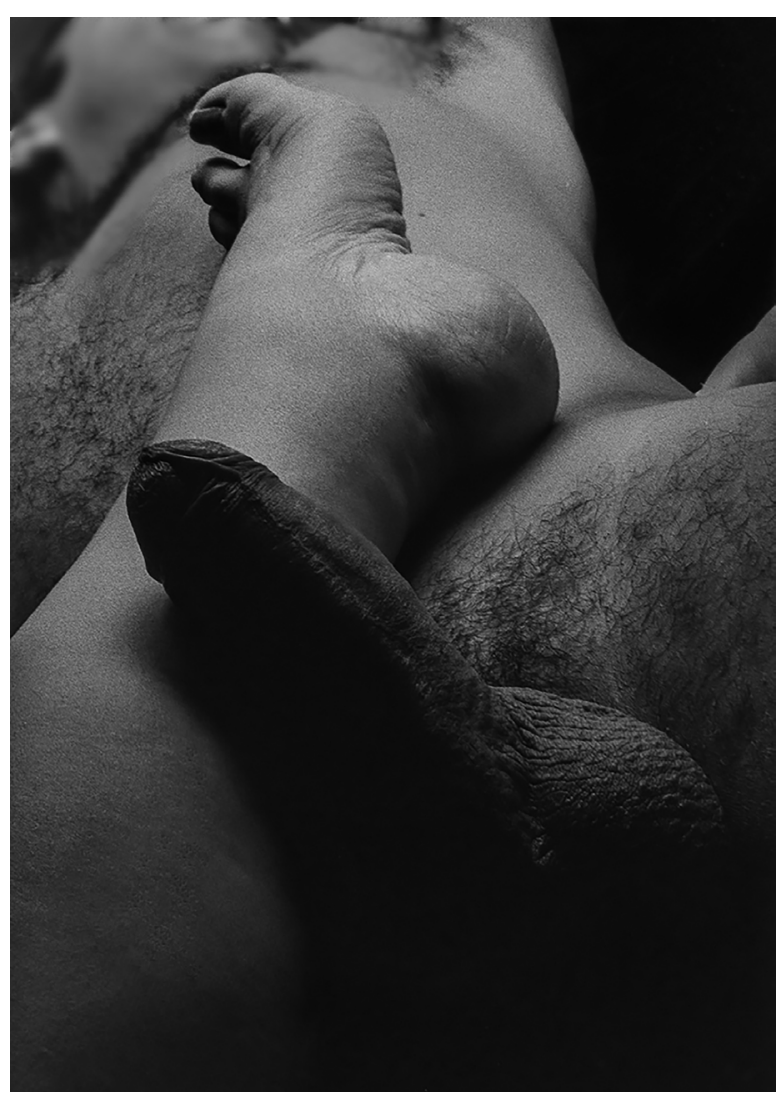

Fuente: Adela Marín

que aborda el tema del desnudo masculino desde la perspectiva erótica. En su ensayo $Y o$ como voyeur (2002-2004), explora detalles del cuerpo masculino y, además, la misma artista se integra en la fotografía, rompiendo con todo paradigma de la construcción de lo femenino al transformarse, en sus imágenes, en un elemento activo que no solo asume su derecho de mirar, sino de ser parte. "Adela Marín [...] contempla la fuerza del cuerpo, 


\section{Artículos}

y logra entablar -desde el lado del espectador- una mirada a la fogosa sensualidad, y a esos signos de la masculinidad que, a algunos incomoda, o, por el contrario, impacta." (Quirós, 2012, p.4).

A pesar de que no ha recibido censura donde se le ha expuesto, la obra sí ha generado reacciones con respecto a lo impropio de una mujer fotografiando el tema. Ejemplo de esto son los comentarios de otros artistas pidiendo que sus trabajos no se colocaran a la par de dichas fotografías. Muchos pensaron que las imágenes habían sido realizadas por un fotógrafo gay y no por una mujer. Junto a Marín, otras fotógrafas como Roxana Nagygeller y Tatiana Estrada, abordaron también el tema sin encontrar espacio para mostrar su obra (Vargas, 2003).

En el año 2008, de igual forma, se censuró la exposición El Jardín de las Delicias, del Colectivo de Artistas Costarricenses, muestra comprendida por esculturas en gran formato realizadas con tela y objetos, la cual se exhibió en La Facultad de Filosofía de la Universidad Nacional. Pese a que la muestra ya había sido vista por más de 70.000 personas en el Festival de las Artes de ese año, los penes de las obras, que eran de tela, fueron cubiertos por bolsas negras para evitar, según la decana Luisa Chacón, que fueran vistas por los niños que visiten el recinto. Invocando este argumento también fueron censuradas las obras de las artistas Zulay Soto y Leda Astorga, en diferentes momentos.
Figura 15

Vergüenza Ajena (2015)

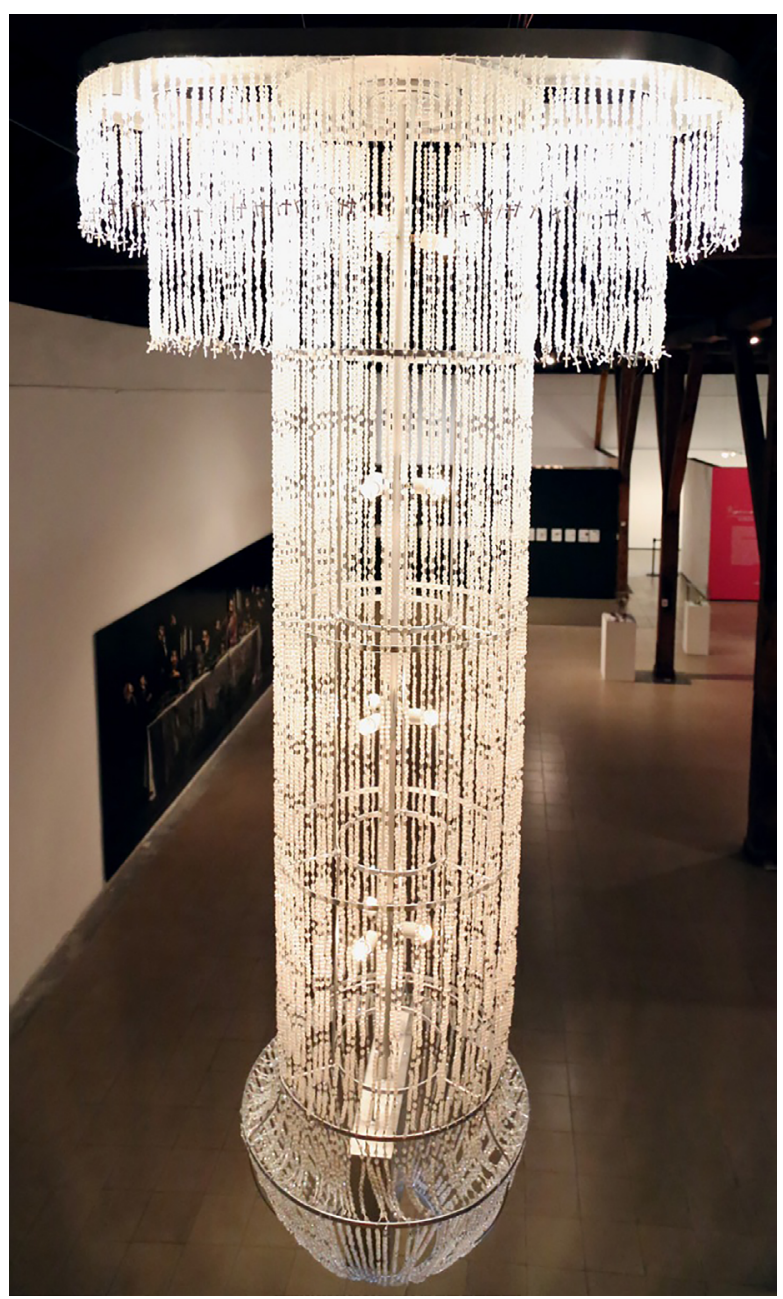

Fuente: Roberto Guerrero

En medio de este panorama surge Roberto Guerrero (1978), uno de los artistas jóvenes que con mayor solidez. Desde el inicio de su carrera, este ha ido trabajando el tema de su propio cuerpo, cargado de elementos simbólicos. La apropiación iconográfica desde lo lúdico con elementos que resquebrajan el 
concepto de la masculinidad, la represión, el homoerotismo y la teoría queer ante la represión sexual. Su trabajo ha integrado la fotografía analógica y digital en diferentes formatos y materiales, así como la instalación y el videoarte. En su exposición retrospectiva Vergüenza Ajena (2015), también ganadora del Premio Nacional Aquileo J. Echeverría (2015), un enorme falo de cristales iluminados, suspendido del techo de la galería, recibía a los espectadores (Fig. 15), quienes se veían inmersos en medio de un discurso dif ícil de digerir en una Costa Rica que se atreve a la tolerancia hacia algunos sectores de la cultura sexual marginal pero, a la vez, se enfrenta con las directrices religiosas y la doble moral.

\section{A manera de conclusión}

Las nuevas tecnologías van a replantear una nueva estructura de los paradigmas sociales. El espacio expositivo ya no se circunscribe a la galería o al museo ni queda limitado a las decisiones curatoriales; los espacios virtuales se transforman en una plataforma para expresarse libremente, convirtiéndose así en el terreno idóneo para que artistas contemporáneos, artistas plásticos, fotógrafos y videocreadores pueden expresar sin restricciones su particular visión de la vida y hablar de temas controversiales o polémicos. Este espacio, si bien es virtual, llega a muchísima más gente que cualquier otro espacio expositivo tradicional. Galerías como El Museo de las Mujeres (2012) dirigida por Claudia Mandel, da voz a expresiones del arte expresado por féminas, el cual aborda temas complejos de los que no se había hablado antes, más allá de una visión heteronormativa.

Artistas jóvenes como Mario Acosta o Lingie Granados apuestan por trabajar el tema desde la metáfora y el diseño con su propuesta Genitalia (2014) (Fig.16); pero, de igual manera, su obra, que integra lo sugerente con un texto explicativo, fue también censurada. Alejandra Guzmán (Fig.19) pese a las críticas y a la oposición aún trabaja, al igual que Andrés Rangel (Fig.17), desde el lenguaje de lo directo. Por otro lado, la joven ilustradora Stephanie Chávez-Lizano (1990), destaca por su trabajo en el tema del deseo y lo absolutamente sexual,

\section{Figura 16 \\ Manuales Genitalia (2015)}

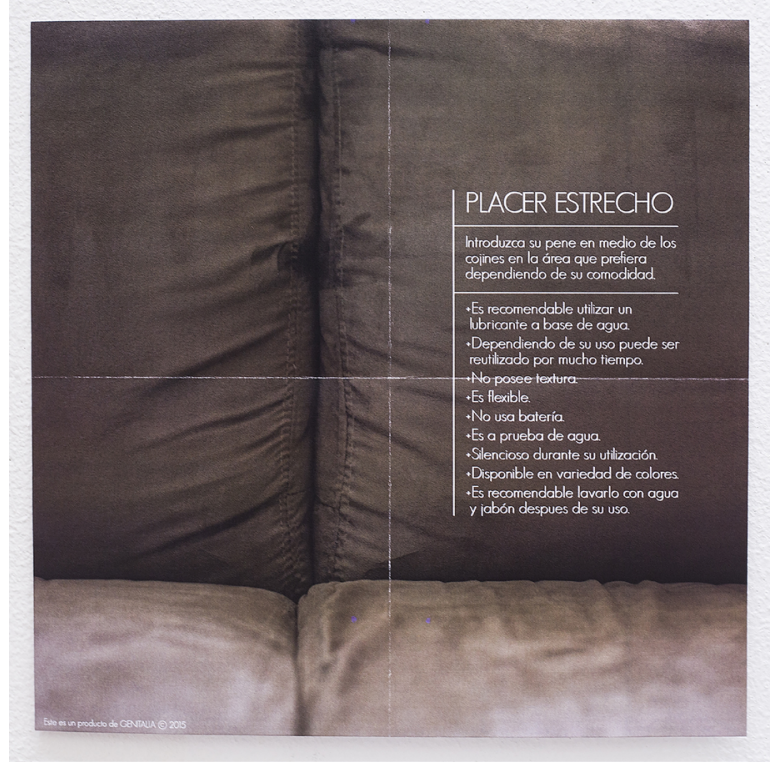

Fuente: Mario Acosta y Lingie Granados 


\section{Artículos}

\section{Figura 17}

Mandamientos. "No tocarás tu melocotón" (2013-2014)

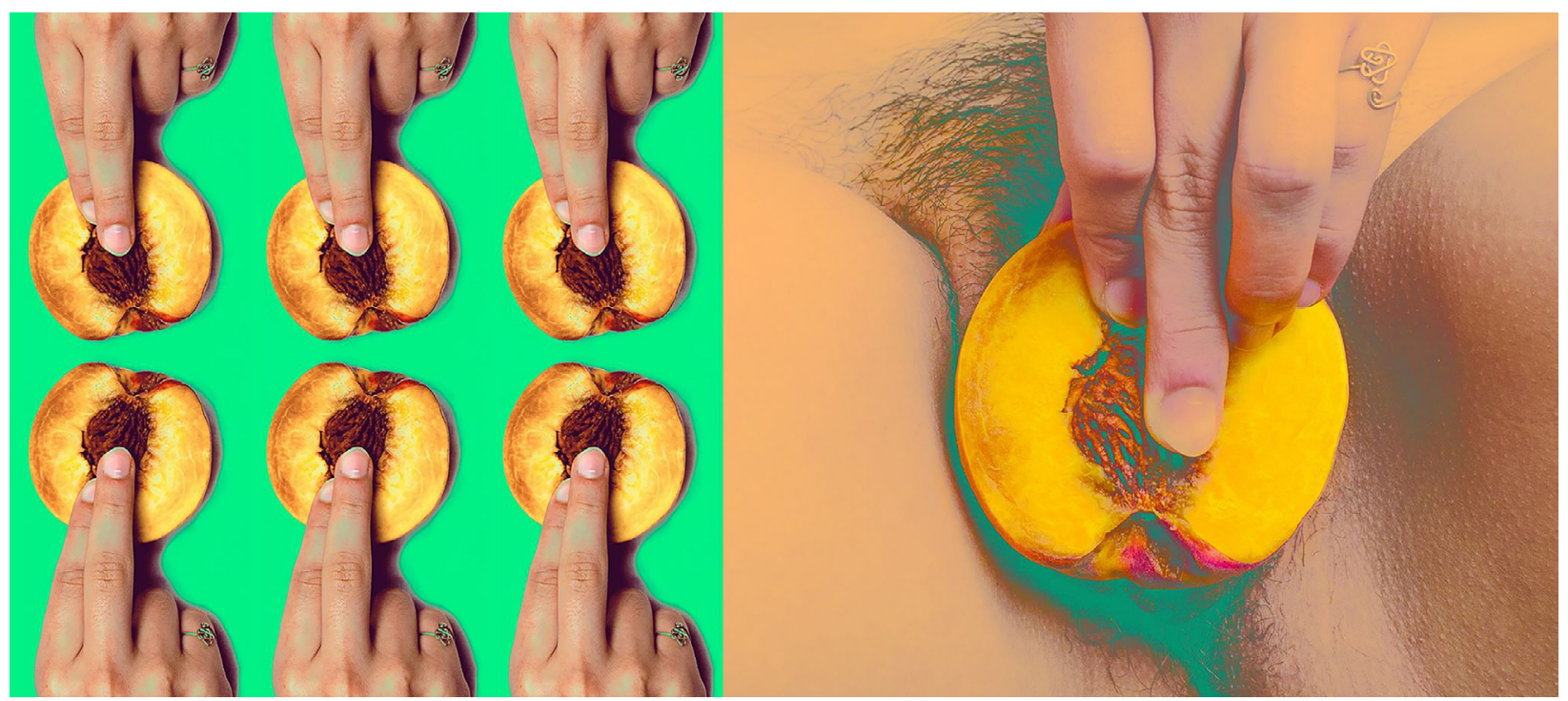

Fuente: Andrés Rangel

desde lo lúdico e irreverente (Fig.18) y suele ser censurada repetidamente en redes sociales por lo directo de sus trabajos.

La ambivalencia entre lo pornográfico y el arte erótico, no es tan sustancialmente diferente, pues en la mayoría de los casos va a depender fundamentalmente del espacio en el que se mire y también de quien lo mire. Mucha de la censura generada, especialmente en los últimos años, se ha dado porque las obras han sido mostradas en espacios no expositivos; inclusive lo exhibido en Internet ha sido objeto de fuertes restricciones. La censura ha estado y estará en las estructuras de la sociedad que sigue siendo regida por normas tradicionales, bajo una doctrina religiosa imperante, que pierde el poder ante nuevos paradigmas de la construcción de los imaginarios sociales.

Figura 18

Sin título (2014)

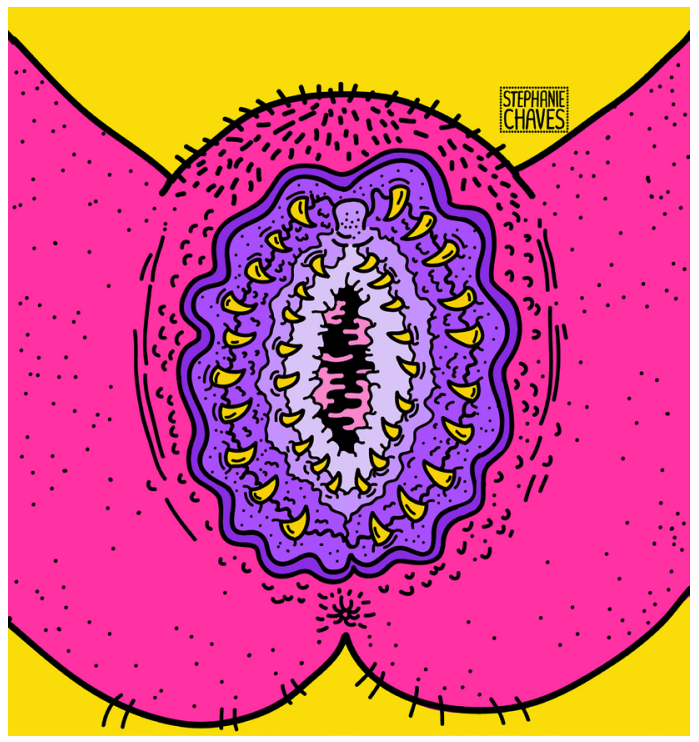

Fuente: Stephanie Chávez 
Figura 19

Mi propia incomodidad (2012)

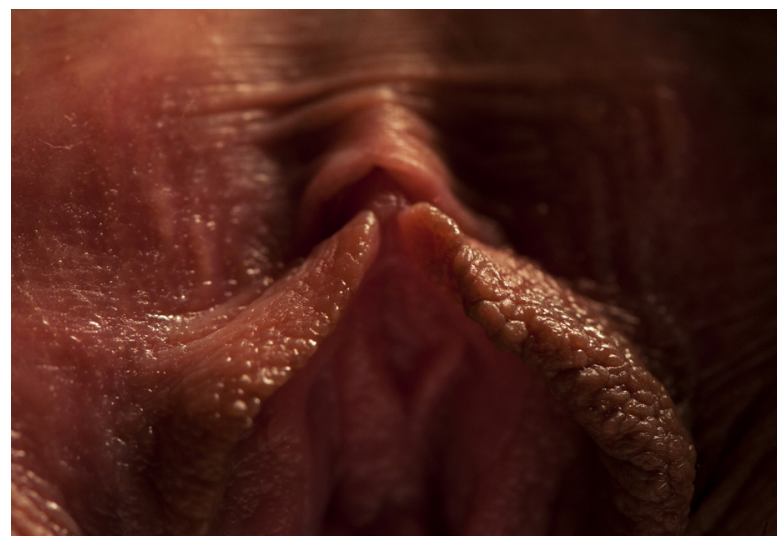

Fuente: Alejandra Guzmán

Después de este proceso de ordenamiento taxonómico, podemos ver cómo a lo largo de nuestra historia la obra de arte ha sido censurada. Es interesante analizar también cómo en esta época, en la que estamos expuestos a tantas imágenes hipersexualizadas, tanto en el cine, la televisión, los medios impresos y digitales como en la publicidad y las estrategias de mercado, todavía se restringen espacios; se omiten datos importantes en la historia oficial del arte; se niega la posibilidad de conocer el trabajo que muchos artistas realizaron sobre el tema; se reacciona al miedo por la opinión pública y se condena la cuestión por considerarla todavía un tabú del que no se debe hablar, aunque se hable. La creación artística -irónicamente- es censurada, en contraposición con toda la información sexualizada que bombardea día a día en los medios, lo cual no tiene sentido ante este lenguaje permanentemente deconstructivo del arte.

\section{Referencias}

Alvarado, I. y Hernández, E. (2000). Catálogo Exposición "Imágenes de Hombres". Costa Rica: Museos del Banco Central.

Archivo Nacional. (2011). El Álbum de Figueroa. Un viaje por las páginas del tiempo. San José, Costa Rica: Editoriales Universitarias Públicas Costarricenses.

Campos, M. (1997). Retrato de la Intolerancia. Revista Rumbo, 668: 38-41.

Cao, M. (1999). Creación artística y mujeres. Madrid: Editorial Narcea.

Carreño, G. (2002). Fotografías de cuerpos indígenas y la mirada erótica: reflexiones preliminares sobre algunos casos del confín austral. Revista Chilena de Antropología Visual, 2: 133-153.

Casares, E. (1998). Los Hilos del Deseo. Jaime-David Tischler. Threads of desire. INTAR Latin American Gallery.

Castro-Rodríguez, A. (2009). Pecados Nefandos. Costa Rica: Universidad Veritas, Escuela de Fotografía.

Ewing. W. A. (1996). El Cuerpo. Londres: Ediciones Ciruela.

Ferrero, L. (1981). Costa Rica Precolombina. San José, Costa Rica: Editorial Costa Rica.

Ferrero, L. (1986). Sociedad y arte en la Costa Rica del siglo XIX. Costa Rica: EUNED.

Fobias.Net. (s.f.). Nudofobia. Recuperado de http://www.fobias.net/Nudofobia.html 


\section{Artículos}

Instituto Nacional de Bellas Artes. (1994). Francisco Zúñiga. Homenaje Nacional. México: Consejo Nacional para la Cultura y las Artes.

Istarú, A. (1983). La estación de fiebre. Poema XVII.. San José, Costa Rica: EDUCA.

Krumbrach, H. (1996). Moral y sexualidad en las culturas de la antigua América. Quetzal Magazine. Recuperado de http:// www.quetzal-leipzig.de/spanische-literatur/moral-y-sexualidad-en-las-culturas-de-la-antigua-america-19093.html

Mandel, C. (2010). Mapa del Cuerpo Femenino. Una lectura deconstructiva de creadoras visuales en Costa Rica. San José, Costa Rica: Editorial de la Universidad de Costa Rica.

Mataró, P. (15 de julio de 1924). Convocatoria para una exposición artística. Diario de Costa Rica, p.11.

Museo de Arte Costarricense. (2008). Juan Manuel Sánchez. Escultor. San José, Costa Rica: Museo de Arte Costarricense.

Museo de Arte Costarricense. (2008). Tamara Ávalos: Hija de Eva. San José, Costa Rica: Museo de Arte Costarricense.

Pérez, D. (2004). La Certeza Vulnerable en el Siglo XXI . Barcelona: Editorial Gustavo Gili.

Porras, C. (2010). Comp. Figuras y Figurones: José María Figueroa Oreamuno. San José, Costa Rica: Fundación Escuela para Todos
Quirós, L. F. (2015). La fotografía y su impacto en Costa Rica. Experimenta Magazine. Recuperado de http://www.experimenta. es/blog/luis-fernando-quiros/la-fotografia-y-su-impacto-en-costa-rica-3334/

Rojas, J. M. y Gutiérrez, F. (5 de octubre de 1997). Artista contemporáneo en medio de la nada. La Nación, Suplemento Áncora: 1-2.

Schapiro-Meyer, M. (1996). Anatomía patológica en figuras indígenas costarricenses. Revista médica costarricense, 26(3): 201209. Recuperado de http://www.binasss. sa.cr/revistas/rmcc/rmedica/418/art7

Taylor, W. (2000). Desnudos eróticos del pasado. Barcelona: Ultramar Editores S.A.

Universidad de Castilla-La Mancha (2015). Iconografía y Contrarreforma. Castilla, La Mancha: Departamento de Historia del Arte. Recuperado de https://www. uclm.es/profesorado/ramonvicentediaz/ textos\%20arte/Iconografia\%20y\%20contrarreforma.htm

Vargas-Alvarado, S. (1983). Las formas del deseo. ArtStudio Magazine. Recuperado de http://www.artstudiomagazine.com/ fotografia/desnudo-masculino.html

Zavaleta E. (2004). Las exposiciones de Artes Plásticas en Costa Rica (1928-1937). San José, Costa Rica: Editorial Universidad de Costa Rica. 